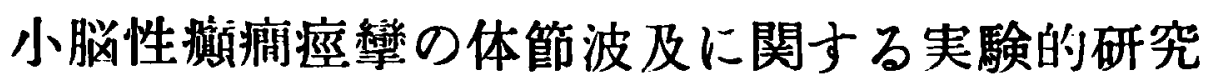

\author{
（本研究は父部省科学研究费の補助による）

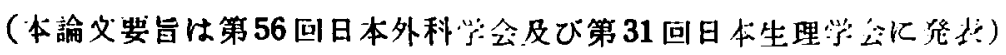

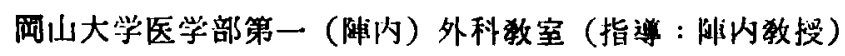 \\ 医学士小坂二度見
}

〔昭和 31 年 3 月 30 日受稿〕

\section{内容目次}

第 1 章 緒言赔に文献

第 2 章 尖験材料站飞実験力涉

第3 章 尘験成 績

第 1 節 小脳皮質及び小脳核刺戟による 疗變の体節波及について

第 1 項 Lobus Junatus anterior 刺战

第 2 項 Lobus lunatus inferior 刺戙

第 3 項 Lobus semilunaris 刺㦸

第 4 項 小脳虫部刺戟

第 5 項 小脳核刺戟

第 6 項 小 括

第 2 節 視床剔除後, 小脳皮質刺戟によ る㽷彎の体節波及について

第 1 項 一側視床剔除後, 同側 L. 1. ant. 刺戟

第 2 項 一側視床剔除後, 同側 L. I. inf. 刺戟

第 3 項 一側視床剔除後, 反対側 L. I. ant. 刺韩

第 4 項 一側視床剔除後, 反対側 L. I. inf. 刺戟

第 5 項 両側視床剔除後, 一側 L. 1 . ant. 及び L. l.inf. 刺戟

第 6 項 小 括

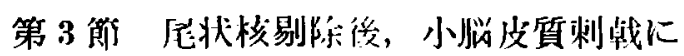

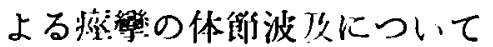

第 1 䐜一侧质状核剔除後，同倒 L.I. ant. 刺韩

第 2 項一侧毛状核剔除後, 同侧 I. I . inf. 刺㦸
罉 3 項一側毛状核剔除後，反刘側 I。 I. ant. 籼戟

第 4 項一側尾状核剔除後，反对倒 L。 1. inf. 刺戟

第 5 項 小 括

第 4 節 レンズ核剔除後，小兴皮質刺战 による痛攣の体卿波及について

第 1 項 一側レンズ核剔除後，同倒 $\mathrm{L}$ 。 I. ant. 刺戟

第 2 項 一側レンズ核剔除後，同侧 $\mathrm{L}$ 。 1. inf. 刺戟

第3 項一側レンズ核剔除後, 反対僛 L. I. ant. 刺戟

第 4 項 一側レンズ核剔除後, 反对側 L. 1. inf. 刺载

第 5 項 雨側レンズ核剔除瑷，一側 L。 I. ant. 及び 1. I. inf. 刺戟

第 6 項 小 括

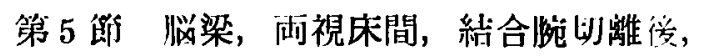
小脳皮質刺戟飞よる痖攣の体節 波及について

第 1 項 脳梁切離後，一側 L. I. ant. 及 び L. l.inf. 刺载

第 2 項 而視床閒切離後, 一側 I. 1 . an1. 队び L.1. inf. 刺戟

第 8 項 一倒絬合暆切離後, 同倒 L. . ant. 及び L. I. inf. 刺戟

第 4 項 一側結合腕切離後, 反対側 $\mathrm{I}$. 1. an1. 以び 1.1. inf. 刺戟

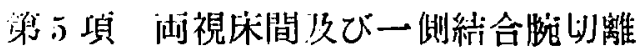


徯, 反対倒 L. I. ant. 及び J 1. inf. 制战

第 6 項車視床間及び一側結合腕切踓: 後, 同側 L.I. ant. 及び L.!. inf. 剌戟

第 7 項 小 括

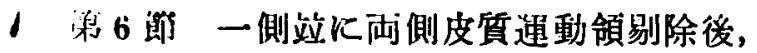
小脳皮質刺㦸による流攣の侑䬦 波及飞ついて

第 1 項 一側皮質速動領剔除後，同側

\section{第1章 腥言竝に文献}

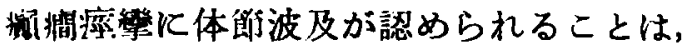

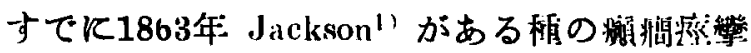

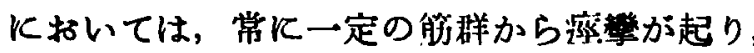
それが順次他の筋群に波及して行く現象を認 めて “March of spasm”と称し，これが大脸 皮質の Rolando 氏領野飞打ける運動中枢の陑' 列飞従つて起ることを報告した。 その後

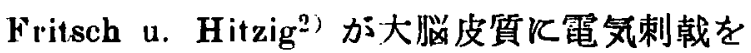
与えると運動が起ることを報告して以来，諸 家によつて㥵ついで火脳皮質道動領に関する 幾多の貴重な研”公が行われた。

一力小胲の運動機能に関しては 1664 年 'Thomas Willis'が小脳は不随意胼を統括する とのべたのを陵矨とし，次いで Luigi Rolando

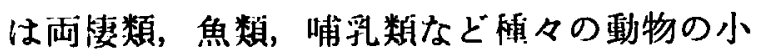
脳を除去した一連の実験より小脳を除去する と随意運動に障碍が起ることを指摘した。 Ferrier'は小脸を”笔気的に刺戟すると眼，䫓， 頌に反応が起ることを認めた。 Luciani' 犬及び猫を用いて小脸剔除奖䮖を行い，犬及 び猫に打いては剔除後 1 週間乃至10日以内で 反弓硬直を起し，主として余身の抗重力能の 强縮性瘵變が生ずるはか震顫の発現するこ とをみている. Sherrington ${ }^{7}$ は小脳の前葉を 電気的に刺戟すると除脳硬直が抑制されるこ とを最初に報告した。最近にいたり $\mathrm{Clark}^{8 / 3}$ ， Ward ${ }^{9}$, Payen", ('owden" 等は猫の大脳及び 小脳皮質の電気刺戟を行つて凐熋を認め，そ の際の march の型を $\mathrm{C}$ 型， $\mathrm{S}$ 型及びU 型の 3 つに分けている. そして小脳制戟の紫合には
L. 1. int. 及ひひ L. 1. inf. 刺戟

第 2 項一側皮質運動領剔除後, 反対 側 L. I. ant. 及び L. I. inf. 刺 韩

第 3 項 両側皮質運動領剔除後，一側 L. 1. ant. 及び L. I. inf. 刺㦸 第 4 項 小 括

第 4 章 総括立位考按

第 5 章 結論 文献

心犁が最も多くみられるとのべている。しか し伝導路飞ついては何すのべていない.

本邦に括いては最近林及びその門下(0)は nicotin, cardiazol 等の化学的刺戟を用いて㩁

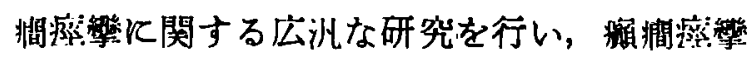
の伝導路を明かにした．この化学的刺戟の特 徵はある濃度では，神経細胞に直接注射され たときにのみ興踾し，神経線維では興窗しな いことで，このことは石塚"1)によつて確めら

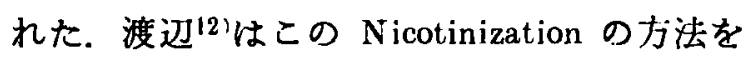
小脳の刺戟に用い，大脳皮質刺戟によつて起

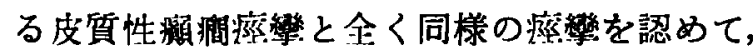

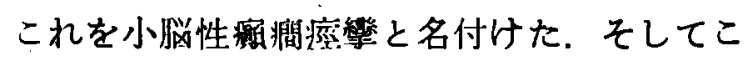
の小脸性傾澗应攣を起すのは小脳両半球皮質 であつて虫部站に小脳諸核の刺戟では起らな いといつている。 またその伝導路に関しては 小脳半球皮質より結合腕を介して反対側視床

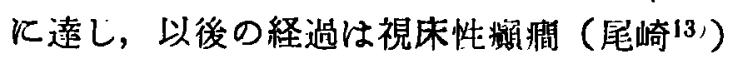
と同粎であるとのへてている.: 教室の吉田'41及

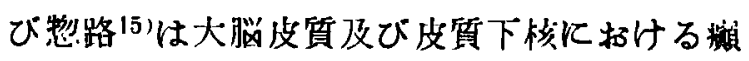

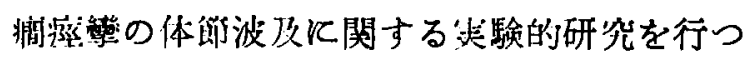
て，絬論として次のことをのべている，1） 皮質連動額，視佅，レンズ㤥，尾状核，黒核 の刺戟によつてあらわれる痛攀には体節波及 が認められる．この体節波及を伴つた应攣が 起るためには皮質通動領の存在が必要である. 2) 㽷酳の一僛半球から反对側半球兄の波及 は視床間で行わ扎る。3）レンズ核と黒核と の間の連終は主として父叉性であるが，僅か ながら弱い同側性の線維があると。

私は教公の吉田, 椠路のあとをつぎ小脳性

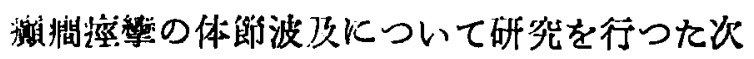


第である。

\section{第2章 実踰材料站に实踰方法}

実験動物には主として体重. $9 \sim 15 \mathrm{~kg}$. の成 犬を使用した。麻酔には $3 \%$ 塩酸モルヒネ溶 液（pro.kilo. 0.5cc）を用いた。

犬はまず固定台上飞腹位にのせ，四肢を軽 く縛り, 固定台踊え付けの顎固定器により上 下額部を充分固定する。これとより䫒部は静 止固定される.

刺戟または剔除を行うための開頭はすへてて 急性実験であるため無消毒のま〉行つた。ま ず苟毛を行い，居間より大後頭結節を過ぎて 項部後端に到る正中皮切を加光る. 皮切飞続 いて最上㕌の菲薄な外耳筋群及び項部に打け る M. sternocleidomastoideus の一部を皮海と 共に両外側飞䧽転する. 次ぎに M. temporalis 及び Planum nuchale K附着せる汸筇を刀ま たは剩離子により骨面より剔離きる。頭骨を

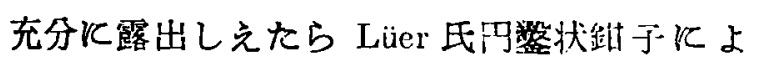
り，実験目的に徒つてそれぞれ側頭䁶，頭頂 骨及び後頭骨を開擎する.

1）小脳皮質露出法

小脸皮質を露出する際 Linea nuchalis sup. の骨隆起中を走る静脈竇の損傷を防ぐため, 刺戟実験に必要とする小脳表面に忍じて開頭 の部位立に広さを加減して行う。このために Linea nuchalis sup. の前方または後方を開頭 する2つの方法炕つて小脳皮質の露出を行 つた.

1）第 1 法 頭蓋骨後面すなわち Planum nuchale の中央部は薄く且つ柔いので，Lüer 氏円整検子でその部分を鉗除すると容易に穿 孔しうる.この小穿孔部より鉗除を四力に搪 大して上方は Linea nuchalis sup. K達する まで，下方は大後頭孔達するまで扇形に開 頭する。この方法によれば Declive, Pyramis, Uvura, Lobus lunatus inferior, Lobus semilunaris 及び小脳諸核の刺戟を行 うことができ る.

口) 第 2 法 Linea nuchalis sup.より前方. 飞扎いて頭頂骨，前頭骨の一部及び側頭骨の
一部を Lüer 氏円整錐子にて切除し，次に露 出された大脳硬脳膜を開き，大脳後頭葉を特 殊金属へラにて前上方に持上げると小脳前面 を得 5 小膜天幕が現れる。この小脸天幕を除 去すれば小脳前半部が現われる。第 2 法によ ると Culmen, Lobus lunatus anterior の刺戟 を行うことができる。

2）小脳皮質及び小脳核制戟方法 刺戟には10\%ペンタソ゚ール液 $(0.05 〜 0.2 \mathrm{cc})$ の局所注射を用いた，私の目的は壆㲛を起す ことのみでなく，痤戀の体節波及を詳細に観 察する必要がある。ペンタゾールを同時に大 量注射すると全身同時の康攣が起りやすいの でまづ0.07〜0.08ccを1回量として注射し て 2〜3 分待ち、これで座卛を起さぬときは さらに同量を追加し, 全量 $0.2 \mathrm{cc}$ まで注射し た.

1）小脸皮質の刺戟にはツヘルクリン注射 器をもつて皮質中約 $1 \mathrm{~mm}$ の深さにペンタゾ 一ル注射を行つた．小脸皮質のうち刺戟を行 つた部位は L. lunatus ant. et. inf., L. semilunaris（これは sup. と inf.をあわせとの後 部を刺戟した), Culmen, Decliv ，Pyramis, Uvula である，小脳皮質の名称を Ellenberger ${ }^{16)}$ 及び Bolk'17)よよて示すと第1図のよ うである。すなわち Ellenberger のいう Lobus lunatus anterior $は$ Bolk $の$ Crus primum lobuli ansiformis (Crus I) K, Lobus lunatus inferior $\&$ Crus secundum lobuli ansiformis (Crus II) K, Lobus semilunaris sup. I Crus ascendens paraflocculi $K$, Lobus semilunaris inf. 2 Crus descendens paraflocculi $K$, Lobus cuneiformis 4 Lobulus paramedianus $飞$ 相当 する.

口) 小脳諸㤥 (N. dentatus, N. interpositus, N. fastigius）の刺戟は渡辺12）の方法によつて 行つた.すなわち注射針をPyramis の辺縁の 中块部より延髄の上面飞水平飞前方飞刺入し， 針の深さ及び外側への角度は第 2 図の如く夫 々の核によつて異る.

小脳核刺戟の場合は $10 \%$ ペンタゾール液に $2 / 10$ 量の墨汁を加并着色し，笑験終了後汇剔 


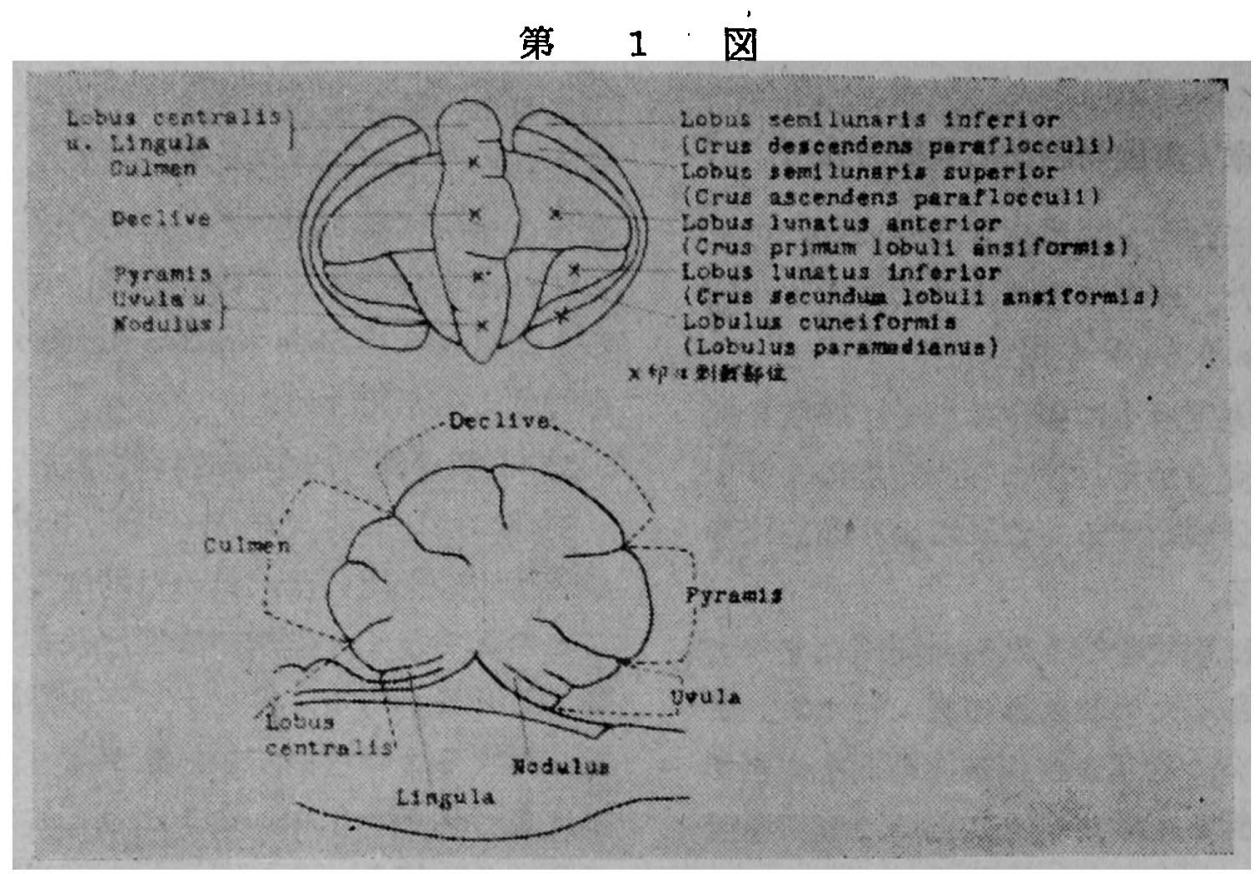

第 2 図小脳核剌戟方法

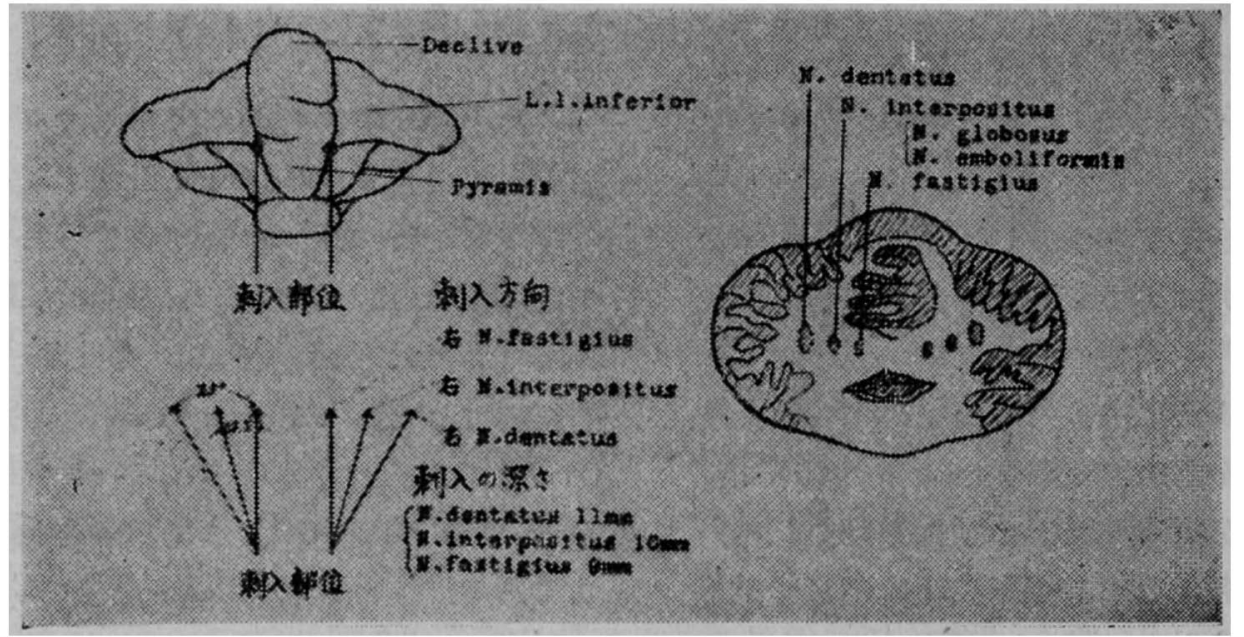

出標本により刺载部位を確かめた。

3）視床剔除方法

Grr. entolateralis に沿つて約 $3 \mathrm{~cm}$ の切開

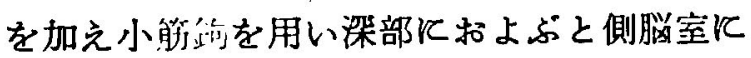
達し, その下に Fornix, Fimbria hippocampi の一部をみることができる. Fornixの前俊に 小切開を加えると，その直下に視床をるとめ ろる。この視床を輪ピンセツトで掬い取るよ ろにして視床剔除を行つた。

4）尾状核剔除方法

尾状核飞達与る方法は前述した視床に達す るカ法とまつたく同様にすれば，視床のやや 前外側部に接して現れてくる.この尾状核を Curetle をるつて剔除した.

5） レンズ核剔除方法
レンズ情够除は被铅，荅球を一括して剔除 した，細い柄を有する Curette $(5 \times 2 \mathrm{~mm})$ を Sulcus ectosylvius medius のところで脳の表 面より垂直に深さ $11 \mathrm{~mm}$ 捜入し, Curette の 尖端が前後 $14 \mathrm{~mm}$, 上下 $11 \mathrm{~mm} の$ 態円形を画 く範囲内を掬い取るよ5にしてレンズ核剔除 を行つた.

6）脸梁切離及び両視床間切離方法 大脳皮質を路出し，大脳半球間裂飞薄い一 ラを挿大して，脉部より膨大部にいたるまで 切離した. 両視床間切離の場合は脳梁の後方 を一部切離し，その間よりへラを深部に插入 して両視床間の切離を行つた。

7）結合腕切離方法

小脳路出法の第 2 法に従つて小脳前面を露 
出し，小脸と下丘との間を制離して深部に進 むと結合椸をるとめうる。これを眼科用メス で切離した。

8）皮質運動領剔除方法

まず Sulcus cruciatus を求め，これを目標 飞教室の森, 沼本 ${ }^{18)}$ とより発表されたサイラ トロン衛慗波発振装置を用いて，運動領野を 決定する. 次に剔除領野の脳血管をとの周囲 凡おいて電気凝固器で凝固切断し, 剔除皮質 領野の周囲に切開を加え，小型スパーテルで $0.3 \sim 0.5 \mathrm{~cm}$ の深さに剔除を行つた.

実験の観察方法としては，とくに正確を期 する目的で 4 チャネル・インク式筋電図記録 装置を用い，四肢の筋肉から筋電図を誘導し $\tau$, march の順序を決定した.

\section{第3帮実験成績}

第1箅 小脳皮質及び小脸核刺戟による痤 攀の体節波及について

第1項 Lobus lunatus anterior 刺戟

困表 1 の

（完全 march の場合）

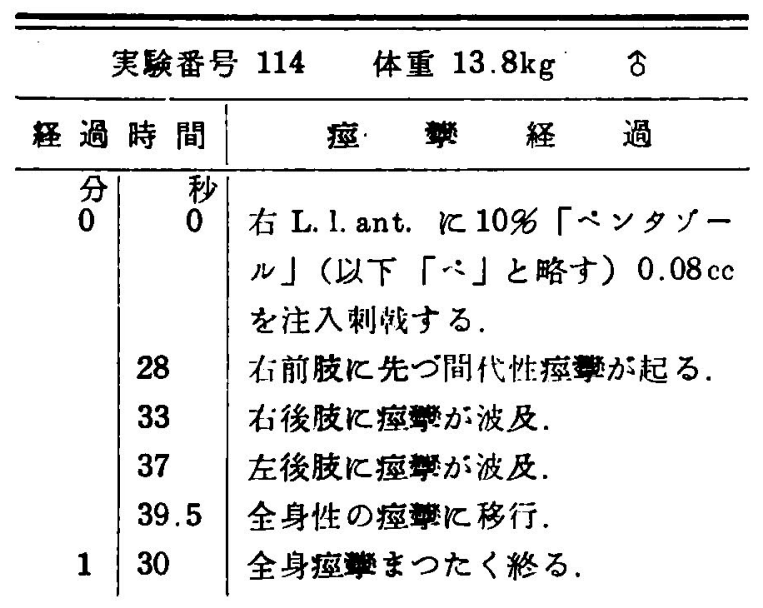

右 L. 1. ant. 刺戟

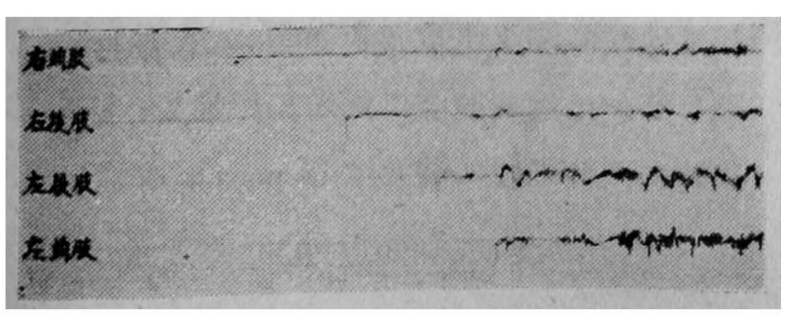

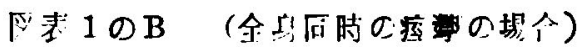

\begin{tabular}{|c|c|c|c|c|c|}
\hline \multicolumn{3}{|c|}{ 実駼番号 115} & \multicolumn{2}{|c|}{ 体 $1.5 \mathrm{~kg}$} & $\hat{0}$ \\
\hline \multicolumn{2}{|c|}{$\begin{array}{c}\text { 実験番是 } \\
\text { 程 過時間間 } \\
\end{array}$} & 痤 & 攀 & 経 & 過 \\
\hline 0八 & $\begin{array}{l}0 \text { 秒 } \\
21\end{array}$ & $\begin{array}{l}\text { 左. L. } 1 . \\
\text { 剌战する } \\
\text { 全身同㭙 }\end{array}$ & $\begin{array}{l}\text { ant. } 反 \\
\text { 寺の痤 }\end{array}$ & 起 & 7ccを注入 \\
\hline 1 & 15 & 全身㽷新 & 封同時 & & \\
\hline
\end{tabular}
左 L. 1. ant. 刺韩

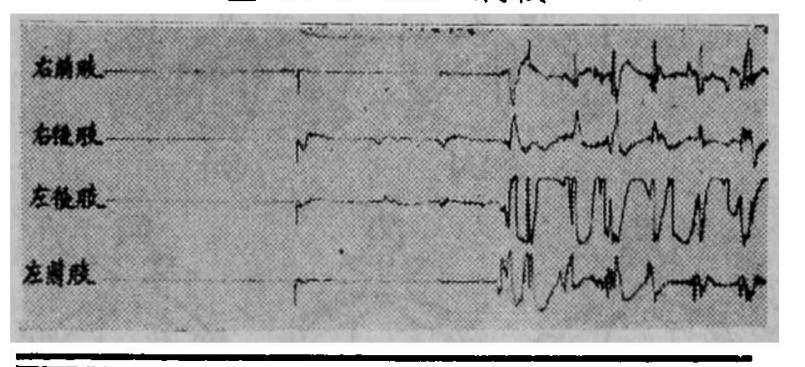

\begin{tabular}{|c|c|c|c|c|c|}
\hline \multicolumn{6}{|c|}{ 右 Lobus lunatus anterior 刺献 } \\
\hline \multirow{2}{*}{ 実験番号 } & \multirow{2}{*}{$\begin{array}{c}\text { MARCH } \\
(-)\end{array}$} & \multicolumn{4}{|c|}{ MARCH $(+)$} \\
\hline & & 不前肢 & 份後肢 & 左後肢 & 左前肢 \\
\hline 101 & 全身同時 & & & & \\
\hline 102 & & (1) & (1) & (2) & (3) \\
\hline 103 & 全身同時 & & & & \\
\hline 104 & 全身同時 & & & & \\
\hline 105 & & (1) & (2) & (3) & (4) \\
\hline 106 & & (1) & (2) & (3) & (4) \\
\hline 107 & 全身同時 & & & & \\
\hline 108 & & (1) & (2) & (3) & (4) \\
\hline 109 & & (2) & (1) & (3) & (4) \\
\hline 110 & 全身同洔 & & & & \\
\hline 111 & & (1) & (2) & (3) & (4) \\
\hline 112 & 全身同時 & & & & \\
\hline 113 & & (1) & (3) & (4) & (2) \\
\hline 114 & & (1) & (2) & (3) & (4) \\
\hline
\end{tabular}

\begin{tabular}{|c|c|c|c|c|c|}
\hline \multicolumn{6}{|c|}{ 在 Lobus lunatus anterior 剌献 } \\
\hline \multirow{2}{*}{ 実験番号 } & \multirow{2}{*}{$\begin{array}{l}\text { MARCH } \\
(-)\end{array}$} & \multicolumn{4}{|c|}{ MARCH $(+)$} \\
\hline & & 隹前肢 & 与後肢! & 疗:後肢 & Ex:前肢 \\
\hline 115 & 全身同㭙 & & & & \\
\hline 116 & 全身同特 & & & & \\
\hline 117 & & (4) & (3) & (2) & (1) \\
\hline 118 & & (1) & (3) & (2) & (1) \\
\hline 119 & & (2) & (3) & (4) & (1) \\
\hline 120 & 全身同封 & & & & \\
\hline 121 & 全身同封 & & & & \\
\hline 122 & & (4) & (3) & (2) & (1) \\
\hline 123 & 全身同時 & & & & \\
\hline 124 & & (2) & (3) & (4) & (1) \\
\hline 125 & & (4) & (3) & (2) & (1) \\
\hline
\end{tabular}


Lobus lunatus anterior 刺戟

図表 1 の

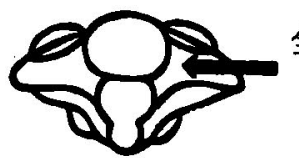
全 25 例 全身同時 11例 ? 一 千 14例

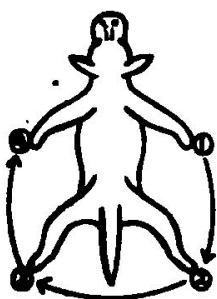

9例

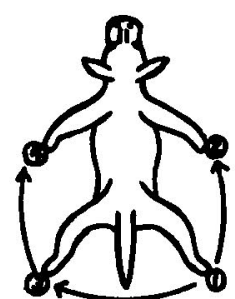

1 㑬

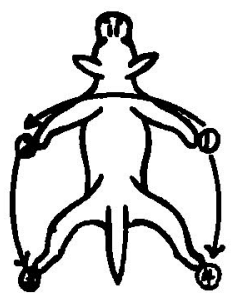

2 例

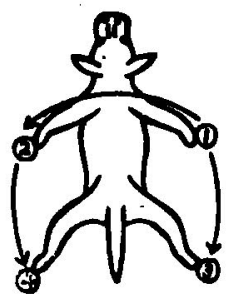

1 㑬

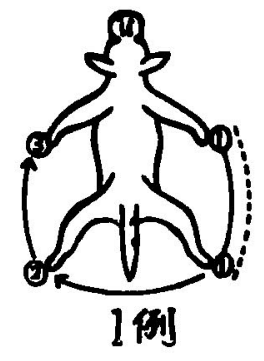

一側の L. 1. ant. を刺戟すると，全 25 例中 14例飞体節波及を伴つた疗攣を認め，残り 11 例飞全身同時の痤攣を認めた。体節波及を認 めた14例中 9 例は，刺戟例の前肢に始発し， 後肢を介乙て他側飞波及する完全 march を 示し，14例中 3 例は刺戟側前肢飞始発し，前 肢を介して他側飞波及する完全 march を示し た. 14 例中 1 例飞刺戟側の後肢に始発し，後 肢を介して他側に波及する完全 march を認め, 残り 1 例飞刺载側の前後肢同時飞始発し, 刺 载反对側の後肢次で前肢と波及する偏側 march を認めた。

第2 項 Lobus lunatus inferior 刺戟 図表 2 （完全 march の場合）

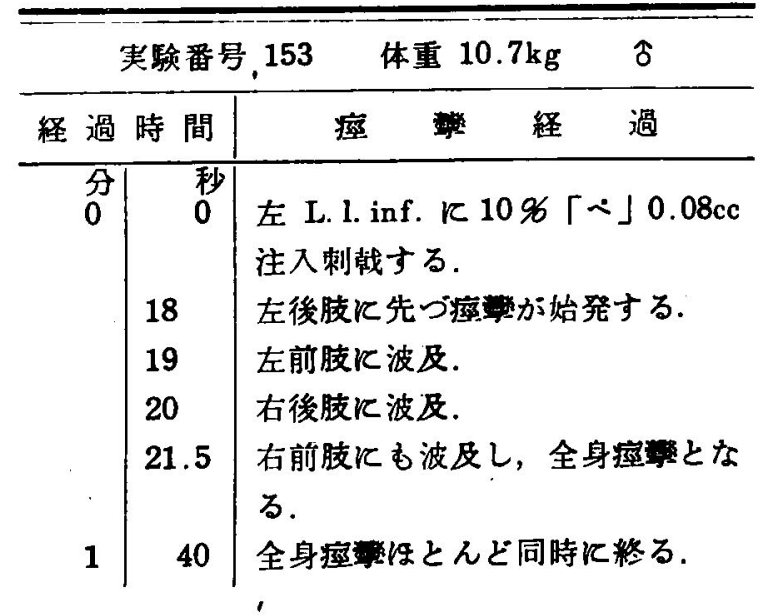

左 L. 1. inf. 刺戟

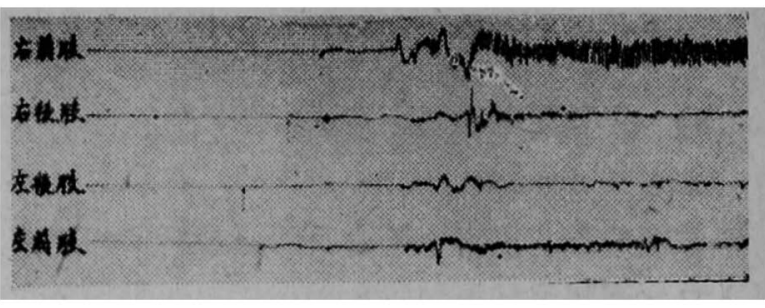

（全身同時の場合）

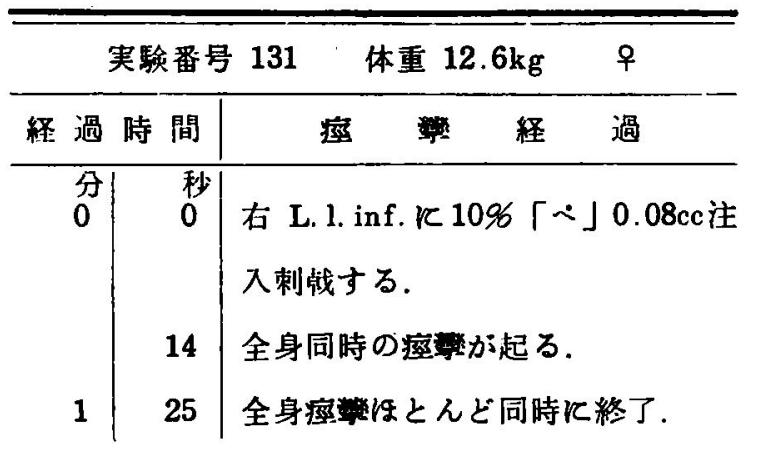

右 L. 1. inf. 刺戟

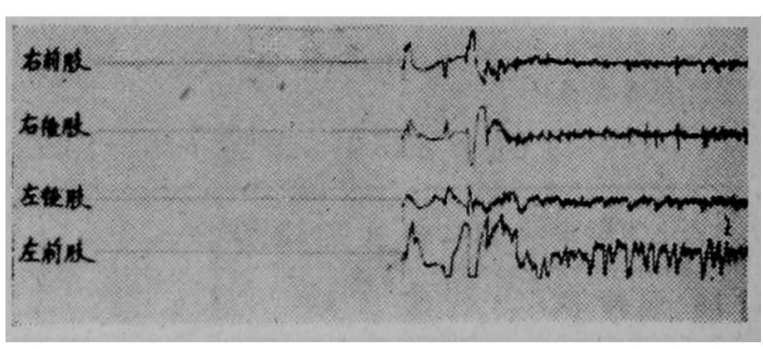

一側の L. 1.inf. を刺戟した場合，全25例中 13例飞体節波及を伴つた㽷攣を認め，残り 13 例には全身同時の涭㝈を認めた。休節波及を 認めた1 3 例中 8 例は刺戟側の後肢に始発し, 後肢を介して他側に波及する完全 $\operatorname{march}$ を 示した. 13例中 3 例は刺戟側前肢より始発し， このうち 2 例は後肢を介し，1例は前肢を介 して他側に波及する完全 march を示した。 残り 2 例は両側後肢に同時に始発し，次いて 同時に両側前肢に波及する march を示した. 


\begin{tabular}{|c|c|c|c|c|c|}
\hline \multicolumn{6}{|c|}{ 有 Lobus lunatus inferior 刺战 } \\
\hline \multirow{2}{*}{ 実験番号 } & \multirow{2}{*}{$\underset{(-)}{\operatorname{MARCH}}$} & \multicolumn{4}{|c|}{ MARCH $(+)$} \\
\hline & & 侣前肢 & 份後胶 & 方:後肢 & 左前肢 \\
\hline 131 & 全身同㭙 & & & & \\
\hline 132 & & (1) & (2) & (3) & (4) \\
\hline 133 & 全身同時 & & & & \\
\hline 134 & & (4) & (1) & (2) & (3) \\
\hline 135 & & (4) & (1) & (2) & (a) \\
\hline 136 & 全身同特 & & & & \\
\hline 137 & 全身同時 & & & & \\
\hline 138 & & (2) & (1) & (1) & (2) \\
\hline 139 & 全身同時 & & & & \\
\hline 140 & 全身同時 & & & & \\
\hline 141 & & (2) & (1) & (3) & (4) \\
\hline 142 & & (2) & (1) & (3) & (4) \\
\hline 143 & & (1) & (2) & (3) & (4) \\
\hline 144 & 全身同時 & & & & \\
\hline
\end{tabular}

Lobus lunatus inferior 刺戟

全 26 例

全身同時 13 例

ᄀ- 于 13 例
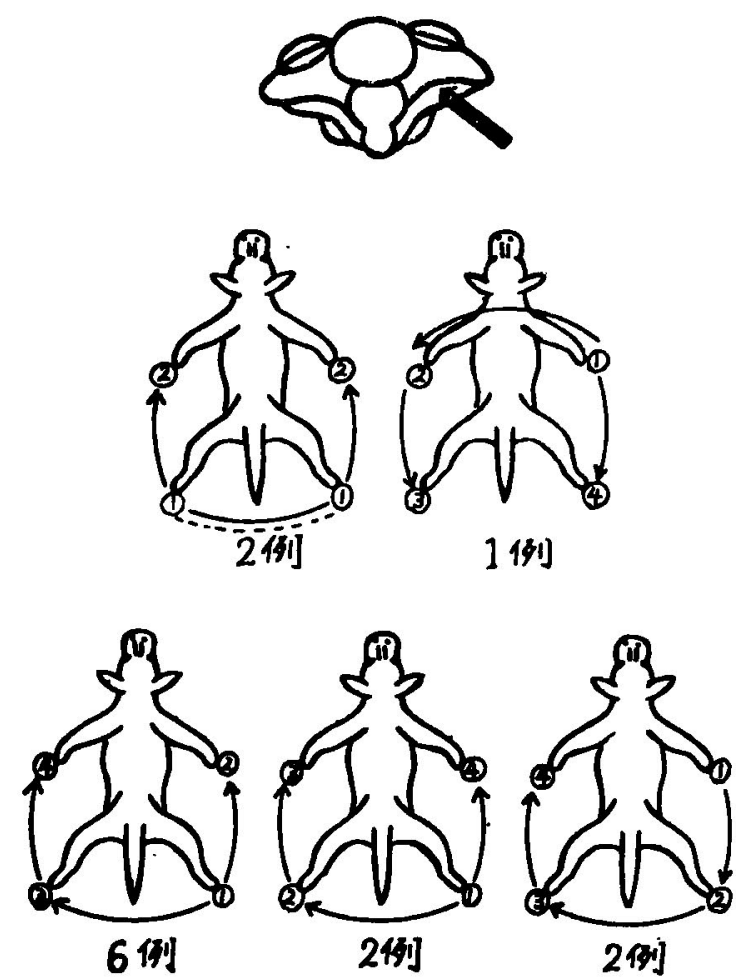

第 3 項 Lobus semilunaris 刺戟

\begin{tabular}{|c|c|c|c|c|c|}
\hline \multicolumn{6}{|c|}{ 左 Lobus lunatus inferior 刺战 } \\
\hline \multirow{2}{*}{ 実験番号 } & \multirow{2}{*}{$\underset{(-)}{\operatorname{MARCH}}$} & \multicolumn{4}{|c|}{ MARCH (+) } \\
\hline & & 份前肢 & 们後胶 & 左後肢 & 左:前肢 \\
\hline 145 & & (4) & (8) & (1) & (2) \\
\hline 146 & 全身同時 & & & & \\
\hline 147 & 全身同恃 & & & & \\
\hline 148 & & (4) & (3) & (1) & (2) \\
\hline 149 & & (2) & (1) & (1) & (2) \\
\hline 150 & 全身同時 & & & & \\
\hline 151 & 全身同時 & & & & \\
\hline 152 & 全身同㭙 & & & & \\
\hline 153 & & (4) & (3) & (1) & (2) \\
\hline 154 & 全身同時 & & & & \\
\hline 155 & & (2) & (3) & (4) & (1) \\
\hline 156 & & (4) & (3) & (1) & (2) \\
\hline
\end{tabular}

因表 3

(完全 march の場合)

\begin{tabular}{|c|c|c|c|c|c|}
\hline & \multicolumn{2}{|c|}{ 実験番号 163} & \multicolumn{2}{|c|}{ 体重 $14 \mathrm{~kg}$} & \multirow{2}{*}{$\frac{\hat{\delta}}{\text { 過， }}$} \\
\hline 経 過 & 時 間 & 痓 & 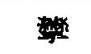 & 経 & \\
\hline $\begin{array}{l}\text { 分 } \\
0\end{array}$ & $\begin{array}{l}55 \\
56 \\
57.5 \\
58.5\end{array}$ & \multicolumn{4}{|c|}{ 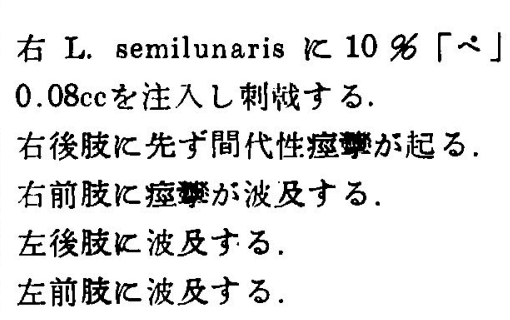 } \\
\hline $\begin{array}{l}1 \\
2\end{array}$ & $\begin{array}{r}5 \\
25\end{array}$ & \multicolumn{4}{|c|}{ 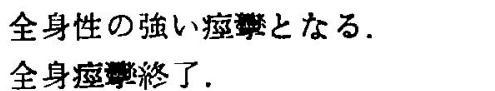 } \\
\hline
\end{tabular}

右 L. semilunaris 剌戟

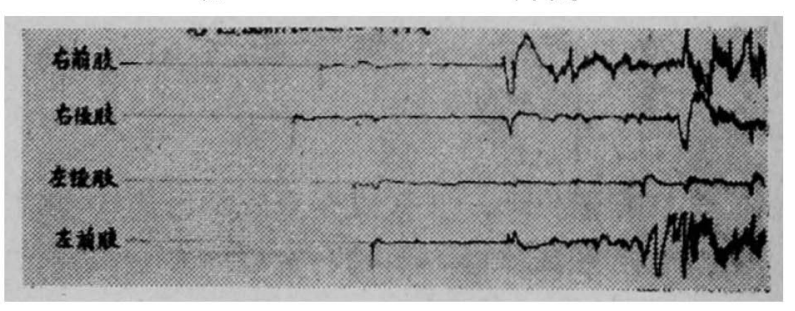

（全身同時の場合）

\begin{tabular}{|c|c|c|c|c|c|}
\hline \multicolumn{3}{|c|}{ 実験番号 161} & \multicolumn{2}{|c|}{ 体重 $10.4 \mathrm{~kg}$} & \multirow{2}{*}{$\frac{\text { 우 }}{\text { 過 }}$} \\
\hline 経，過 & 間 & 疗 & 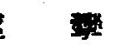 & 経 & \\
\hline $\begin{array}{l}\text { 分 } \\
0\end{array}$ & $\begin{array}{l}\text { 秒 } \\
0 \\
45\end{array}$ & \multicolumn{4}{|c|}{ 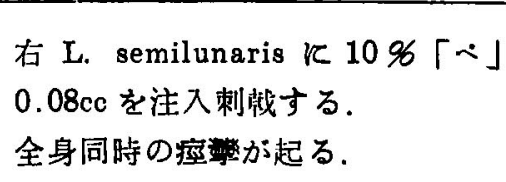 } \\
\hline 1 & 55 & \multicolumn{4}{|c|}{ 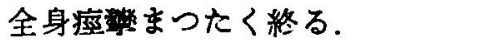 } \\
\hline
\end{tabular}


右L. semilunaris 刺戙

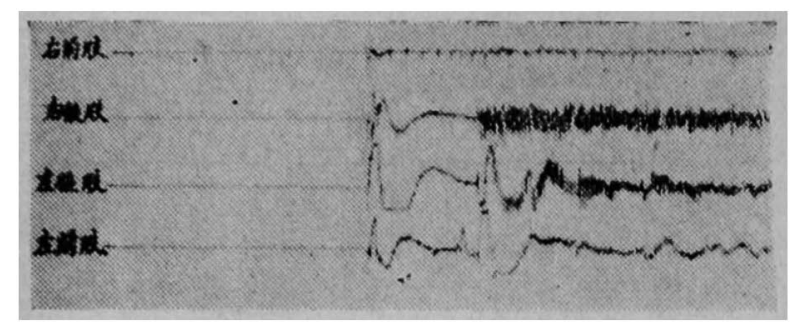

\begin{tabular}{|c|c|c|c|c|c|}
\hline \multicolumn{6}{|c|}{ 右 Lobus semilunaris 刺故 } \\
\hline \multirow{2}{*}{ 実䜽番号 } & \multirow{2}{*}{$\underset{(-)}{\text { MARCH }}$} & \multicolumn{4}{|c|}{ MARCH $(+)$} \\
\hline & & 份前肢 & 石後肢 & 左後肢 & 左前肢 \\
\hline 161 & 全身同時 & & & & \\
\hline 162 & 全身同時 & & & & \\
\hline 163 & & (2) & (1) & (3) & (4) \\
\hline 164 & & (3) & (1) & (4) & (2) \\
\hline 165 & 全身同時 & & & & \\
\hline 166 & & (1) & (2) & (3) & (4) \\
\hline 167 & 全身同時 & & & & \\
\hline 168 & & (4) & (1) & (2) & (3) \\
\hline 169 & 全身同時 & & & & \\
\hline 170 & & (4) & (1) & (2) & (3) \\
\hline 171 & 全身同時 & & & & \\
\hline 172 & & (4) & (1) & (2) & (3) \\
\hline
\end{tabular}

在 Lobus semilunaris 刺战

\begin{tabular}{|c|c|c|c|c|c|}
\hline \multirow{2}{*}{ 実験番号 } & \multirow{2}{*}{$\underset{(-)}{\operatorname{MARCH}}$} & \multicolumn{4}{|c|}{$\operatorname{MARCH}(+)$} \\
\hline & & 右前肢 & 右後肢 & 左後肢 & 左前肢 \\
\hline 173 & 全身同時 & & & & \\
\hline 174 & & (4) & (3) & (1) & (2) \\
\hline 175 & 全身同時 & & & & \\
\hline 176 & & (4) & (2) & (1) & (a) \\
\hline 177 & 全身同㭙 & & & & \\
\hline
\end{tabular}

全17実験例中，9例に全身同時の病卛を認 め，8例飞体節波队を伴つた痙繁を認めた. 休節波及を伴つた 8 例の5ち 6 例は刺戟側の 後肢飞始発し，後肢を介して他側飞波及する 完全 march を認めた。 1 例は刺戟側の前肢 飞始発し，後肢を介して他側飞波及する完全 march を示した。残り工例は刺戟側の後肢に 始発し，刺载反対側前肢，次いで剌戟側前 肢, 刺戟反対側後肢と波及する $\operatorname{march}$ を示し た.
Lolus semilunaris 刺戟。 全 17 例 全身同時 9 例 >-F8例
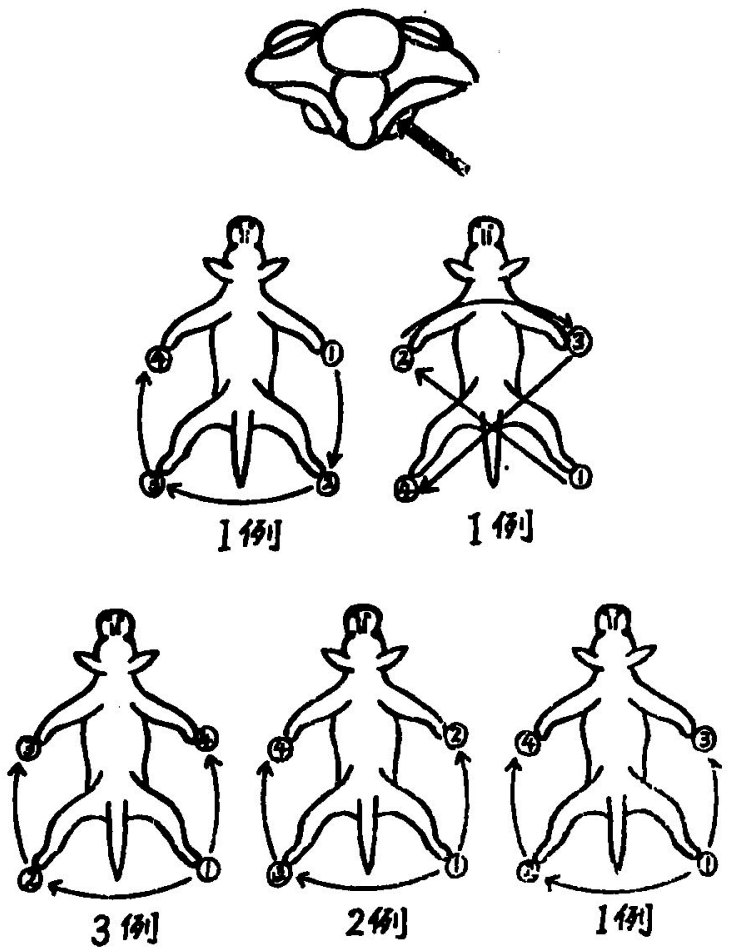

第 4 項 小䑩虫部刺戟

図表 4

\begin{tabular}{|c|c|c|c|c|c|}
\hline & \multicolumn{2}{|c|}{ 実跧番号 184} & 体重 & $0.2 \mathrm{~kg}$ & $\hat{\delta}$ \\
\hline \multicolumn{2}{|c|}{ 経過㭙間 } & 痤 & 样 & 経 & 過 \\
\hline $\begin{array}{c}\text { 分 } \\
0\end{array}$ & $\begin{array}{c}\text { 秒 } \\
0\end{array}$ & \multicolumn{4}{|c|}{$\begin{array}{l}\text { Culmen K } 10 \% \text { 「く」0.06 cc を注入 } \\
\text { 刺战する. }\end{array}$} \\
\hline 2 & 0 & \multicolumn{4}{|c|}{ 痤慗まつたくなし。 } \\
\hline 2 & 10 & \multicolumn{4}{|c|}{ 再注射「へ」 $0.09 \mathrm{cc}$} \\
\hline 10 & 0 & \multicolumn{4}{|c|}{ 丞整を認めず。 } \\
\hline
\end{tabular}

\begin{tabular}{|c|c|c|c|}
\hline 刺战部 位 & 例 数 & 痓繁(+) & 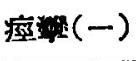 \\
\hline Culmen & 7 & 0 & 7 \\
\hline Declive & 7 & 0 & 7 \\
\hline Pyramis & 7 & 0 & 7 \\
\hline Uvula & 7 & 0 & 7 \\
\hline
\end{tabular}

小脳虫部 (Culmen, Declive, Pyramis, Uvula) の剌载では，実験例それぞれ 7 例のすへてて 痤戀は認められなかつた。 


\begin{tabular}{|c|c|c|c|c|c|}
\hline & \multicolumn{2}{|c|}{ 実験番号 212} & 体重 & $10.5 \mathrm{~kg}$ & $\delta$ \\
\hline \multicolumn{2}{|c|}{ 程過時間 } & 疗 & 辣 & 経 & 過 \\
\hline $\begin{array}{c}\text { 分 } \\
0\end{array}$ & $\begin{array}{c}\text { 秒 } \\
0\end{array}$ & \multirow{2}{*}{\multicolumn{4}{|c|}{$\begin{array}{l}\text { 石 N. dentatus } \\
\text { 注入刺战する. }\end{array}$}} \\
\hline 5 & 0 & & \multicolumn{3}{|c|}{ 察粰生ぜず。 } \\
\hline 5 & 0 & \multicolumn{4}{|c|}{$\begin{array}{l}\text { 右 N. dentatus K再注射「ウ」 } \int 0.2 \mathrm{cc} \\
\text { 注入. }\end{array}$} \\
\hline 10 & 10 & \multicolumn{4}{|c|}{ まつたく痤拏を認めず。 } \\
\hline
\end{tabular}

（痤学を認めた場合）

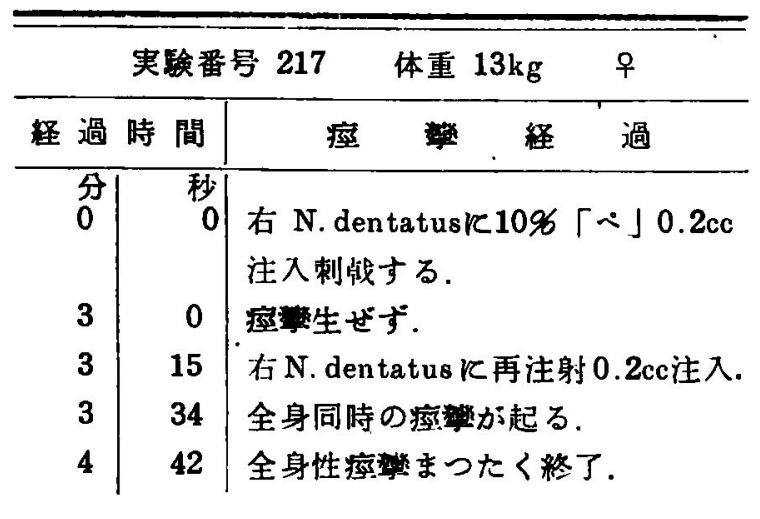

N. dentatus 剌戟

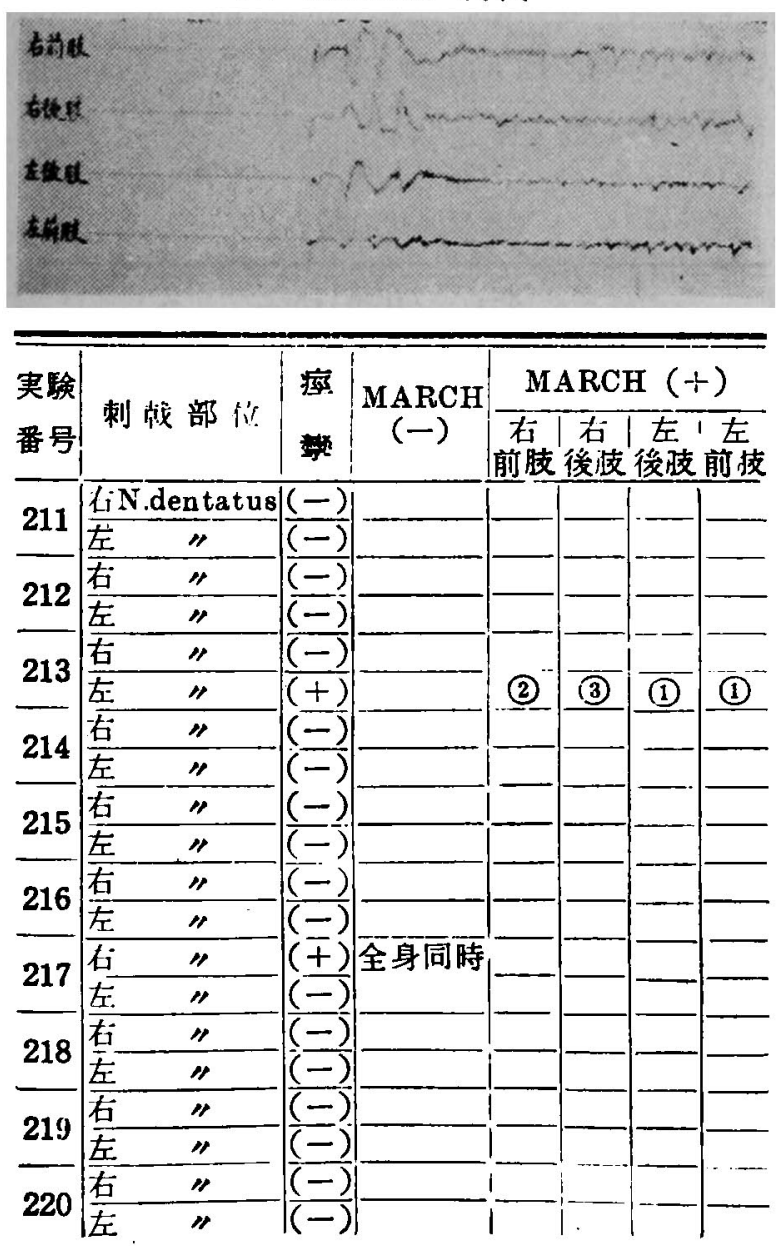

\begin{tabular}{|c|c|c|c|}
\hline 剌战部位 & 例 数 & 病烈( $(+)$ & 㽷杽(一) \\
\hline N. in ter positus & 5 & 0 & 5 \\
\hline N. fastigius & 5 & 0 & 5 \\
\hline
\end{tabular}

N. dentalus 刺戟の場合，刺戟侧20俐中 2 例 にのみ症熊を認めた.すなわち 1 例に企身同 洔の痤攣を認め，他の 1 例には刺戟側の前後 肢同封に始発し，反対側前肢次いで後肢に波 及する marchを認め，他のすへてて瘵戀を認 めなかつた. N. interpositus 狄び $N$. fastigius 剌戟では，笑験例それでれ 5 例のすべてと痤 攣は認められなかつた。

第 6 項 小 括

1）小脳半球皮質（L. 1. ant., L. 1. inf. 及び L. semilunaris）の刺戟では全例飞癲澗痓整が 認められる．この5ち全身同時飞始発するす のと， marchを伴うものがほぼ同数例認め られた。

2） march を伴 5涭攣の場合, L. l. ant. 刺 戟では刺戟側前肢, L. l. inf. 刺戟では主とし て刺戟側後肢，とき飞刺戟側前肢, L. semilunaris 刺䟠では刺戟側後肢より始発する完全 march を示す.

3) 小悩虫部 (Culmen. Declive, Pyramis,

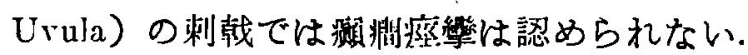

4) 小脳㤥 (N. dentatus, N. interpositus, $\therefore$ fastigius）の剌戟でも一般に痤攀は起り難 W.

第2節 視床剔陨得，小脳皮質刺戟に上る 嫁攀の体節波及飞ついて

第 1 項 一側視床剔除後, 同側 L. l. ant. 刺戟

図表 6 (㨝側 march の場合)

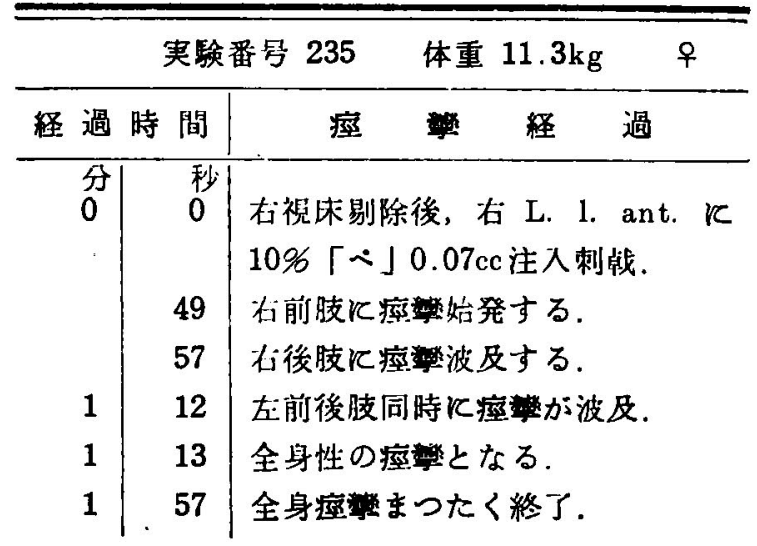


右側視床剔除後, 右 L. 1. ant. 刺戟
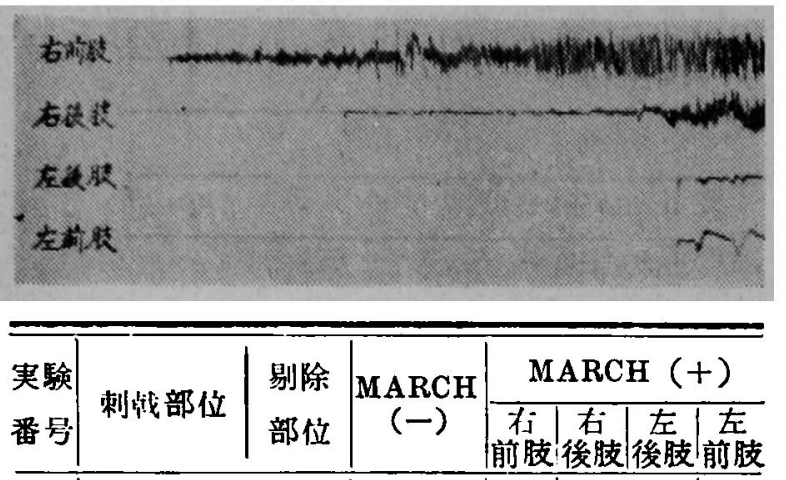

\begin{tabular}{|c|c|c|c|c|c|c|c|}
\hline \multicolumn{3}{|c|}{$231 \mid$ 在L. 1. ant. 份視林 } & & \multirow{2}{*}{$\begin{array}{l}\text { (2) } \\
\text { (1) }\end{array}$} & \multirow{2}{*}{$\begin{array}{l}\text { (1) } \\
\text { (1) }\end{array}$} & \multirow{2}{*}{$\begin{array}{l}\text { (3) } \\
\text { (2) }\end{array}$} & \multirow{2}{*}{\begin{tabular}{|l|} 
(3) \\
(2)
\end{tabular}} \\
\hline 232 & $"$ & " & & & & & \\
\hline 33 & $"$ & $"$ & 全身同時 & & & & \\
\hline 234 & $"$ & $"$ & & (1) & (2) & (3) & (3) \\
\hline 35 & " & $"$ & & (1) & (2) & (a) & (3) \\
\hline 36 & $"$ & $"$ & & (1) & (1) & (2) & (2) \\
\hline 7 & 左L. 1. & 左視床 & 全身同時 & & & & \\
\hline 18 & " & " & & (3) & () & (2) & (1) \\
\hline & $"$ & " & 全身同時 & & & & \\
\hline 240 & " & "r & & (2) & (3) & (2) & (1) \\
\hline 241 & $"$ & $"$ & & (2) & (2) & (1) & (1) \\
\hline & $"$ & $"$ & & $\mid$ (a) $\mid$ & (3) & (2) & (1) \\
\hline
\end{tabular}

この場合は，全実験例 12 例中 9 例飞剔除側 の主として前肢より痤擎が始発し，主として その側には marchを認め，剔除反対側ではす べて march を欠如する偏側 march を示した. 残り 3 例飞は全身同時の庭攣を認めた.

第 2 項 一側視床剔除後, 同側 L. l. inf. 刺戟

この場合は，全実䮖例 7 例中 5 例飞剔除側 の後肢に始発し，その側に march 有し，剔 除反対側飞は march を欠如する偏側 march を認めた。残り2例には全身同時の睉繁を認 めた.

\section{四表 7 (倔側 march の場合)}

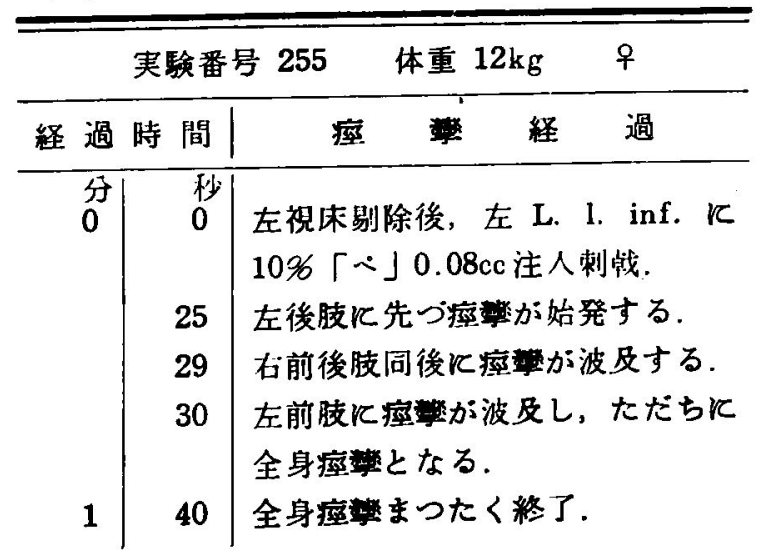

左側視床剔除後, 左 L. 1. inf. 刺戟

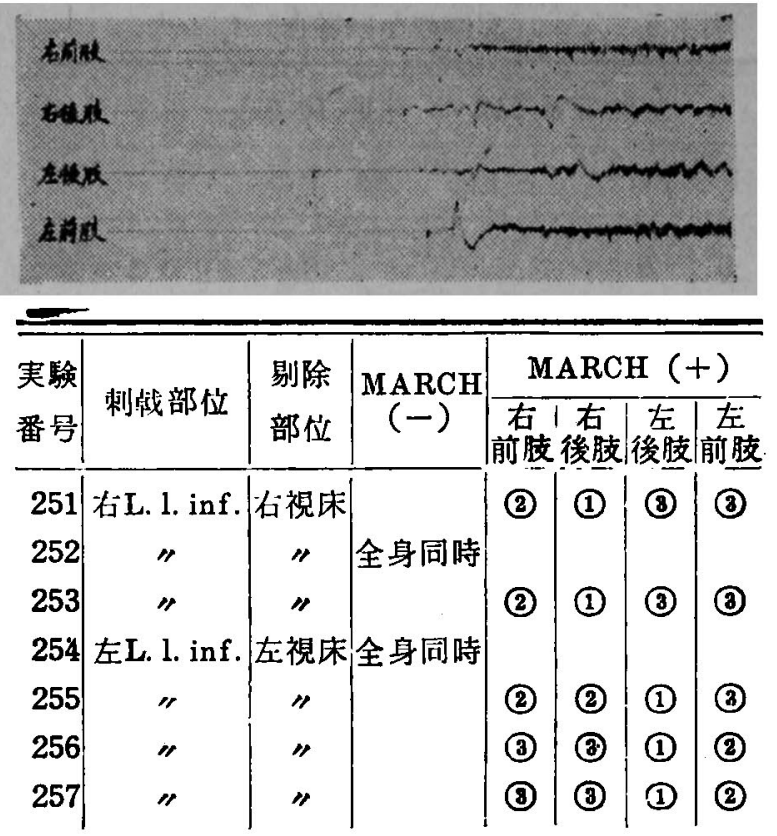

第 3 項 一側視床剔除後, 反対側 L. 1 . ant. 刺韩

この場合は，全実䮖例15例中10k全身同時 の瘵攣を認め, 残りう例には剔除側の前肢ま たは後肢に始発し，その側飞は march を有し， 剔除反対側飞は march を欠如する偏側 march を認めた。

図表 8 （全身同時の場合）

\begin{tabular}{|c|c|c|c|c|c|}
\hline \multicolumn{3}{|c|}{ 実験番号 271} & \multicolumn{2}{|c|}{ 体重 10kg } & \multirow{2}{*}{$\frac{\delta}{\text { 過 }}$} \\
\hline 経 過 日 & 間 & 痤 & 楼 & 経 & \\
\hline $\begin{array}{l}\text { 分 } \\
0\end{array}$ & $\begin{array}{l}\text { 秒 } \\
0\end{array}$ & \multirow{2}{*}{\multicolumn{4}{|c|}{ 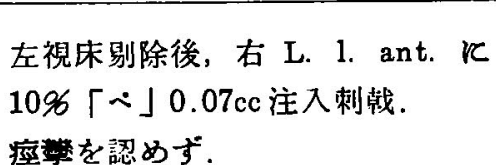 }} \\
\hline 3 & 0 & & & & \\
\hline 3 & 15 & \multirow{3}{*}{\multicolumn{4}{|c|}{$\begin{array}{l}\text { 右 L. l. ant. K再注射 } \\
\text { 全身同㭙の疗等が起る. } \\
\text { 全身疗終了. }\end{array}$}} \\
\hline 3 & 29 & & & & \\
\hline 4 & 10 & & & & \\
\hline
\end{tabular}

左側視床剔除後, 右 L. l. ant. 刺戟

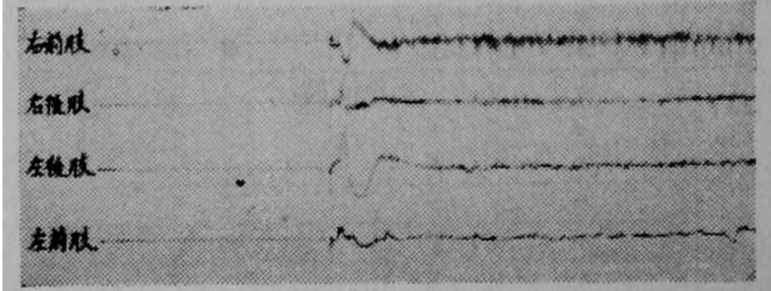


（俑側 march の場合）

\begin{tabular}{|c|c|c|c|c|c|}
\hline \multicolumn{3}{|c|}{ 実験番号 268} & \multicolumn{2}{|c|}{ 体重 $9.7 \mathrm{~kg}$} & \multirow{2}{*}{$\frac{\delta}{\text { 過 }}$} \\
\hline 経 過 & 時 間 & 痤 & 稿 & 経 & \\
\hline $\begin{array}{l}\text { 分 } \\
0\end{array}$ & $\begin{array}{l}\text { 秒 } \\
0\end{array}$ & \multirow{2}{*}{\multicolumn{4}{|c|}{ 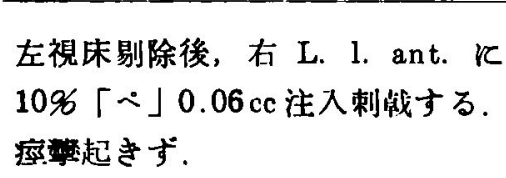 }} \\
\hline 5 & 0 & & & & \\
\hline 5 & 10 & \multicolumn{4}{|c|}{ 右 L. l. ant. K再注射 $(0.07 \mathrm{cc})$. } \\
\hline 5 & 28 & \multicolumn{4}{|c|}{ 左前肢に痤蔜が始発する。 } \\
\hline 5 & 30.5 & \multicolumn{4}{|c|}{ 石前後肢に同時に波及. } \\
\hline 5 & 40.5 & \multicolumn{4}{|c|}{ 左後肢に㾏粯が波及. } \\
\hline 5 & 43 & \multirow{2}{*}{\multicolumn{4}{|c|}{ 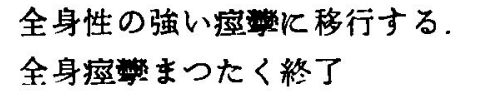 }} \\
\hline 6 & 55 & & & & \\
\hline
\end{tabular}

左側視床剔除低，右 L. J. n.n1. 刺戟
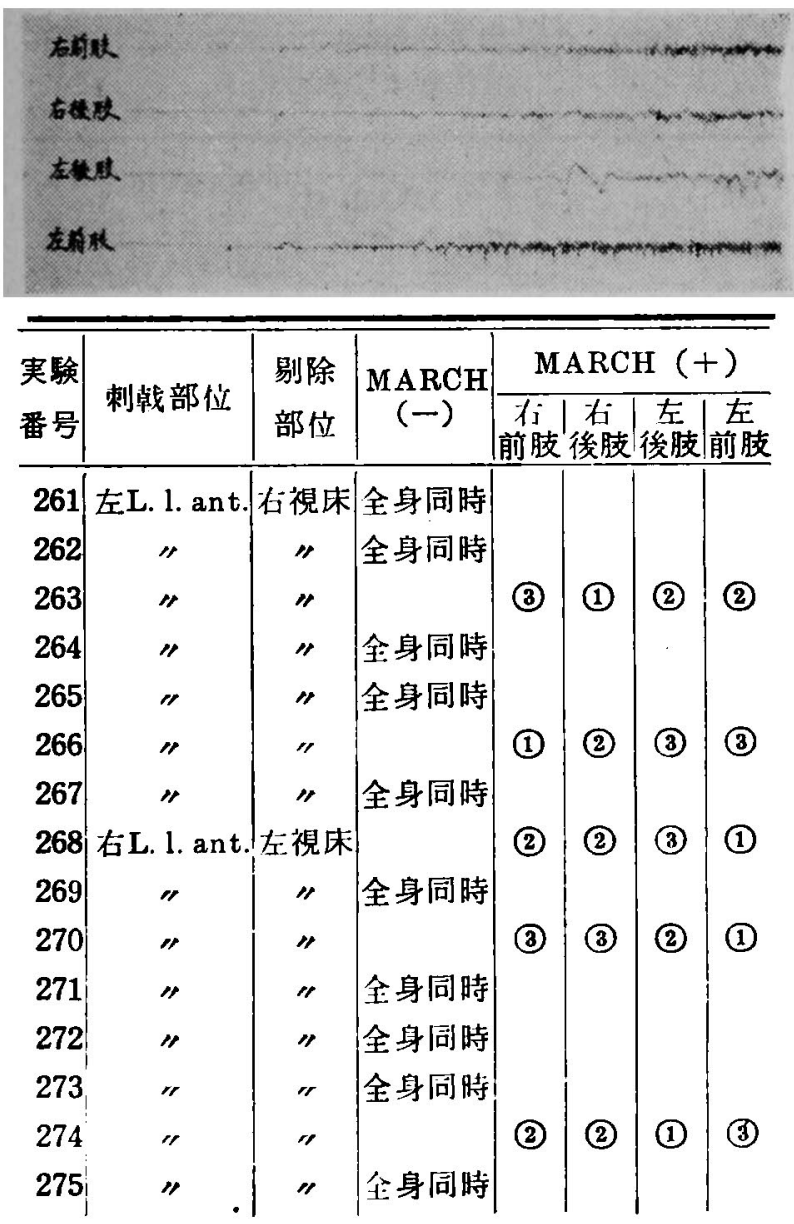

第 4 項 一側視床剔除後, 反対側

$$
\text { L. l. inf. 。剌戟 }
$$

（本項以下飞抢いては筋電図所見を省略する）

この場合は，全奏験例 7 例中 5 例飞全身同 時の座攣を認め, 残り 2 例は剔除側の後肢に 始発し，しかもその側にのみ march を有し 剔除反対側飞は march を欠如する偏側 march を認めた。
図表 9 （全身同㭙の場合）

\begin{tabular}{|c|c|c|c|c|c|}
\hline \multicolumn{3}{|c|}{ 実験番号 284} & \multicolumn{2}{|c|}{ 体重 $12.2 \mathrm{~kg}$} & \multirow{2}{*}{$\frac{\hat{\delta}}{\text { 過 }}$} \\
\hline 経 過 & 時 間 & 丞 & 樊 & 経 & \\
\hline $\begin{array}{l}\text { 分 } \\
0\end{array}$ & $\begin{array}{l}\text { 秒 } \\
0\end{array}$ & \multirow{2}{*}{\multicolumn{4}{|c|}{ 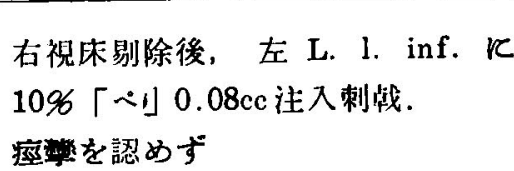 }} \\
\hline 3 & 0 & & & & \\
\hline 3 & 10 & \multicolumn{4}{|c|}{ 左 L. 1. inf. K再注射 $(0.06 \mathrm{cc})$. } \\
\hline 3 & 35 & \multirow{2}{*}{\multicolumn{4}{|c|}{ 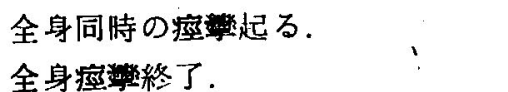 }} \\
\hline 4 & 55 & & & & \\
\hline
\end{tabular}

右側視床剔除後, 左 L. J. inf. 刺戟

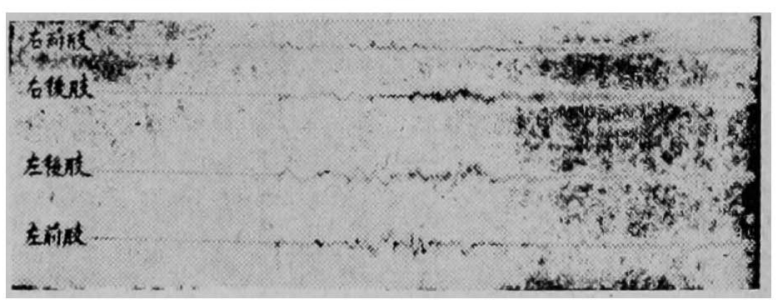

（偏側 march の場合）

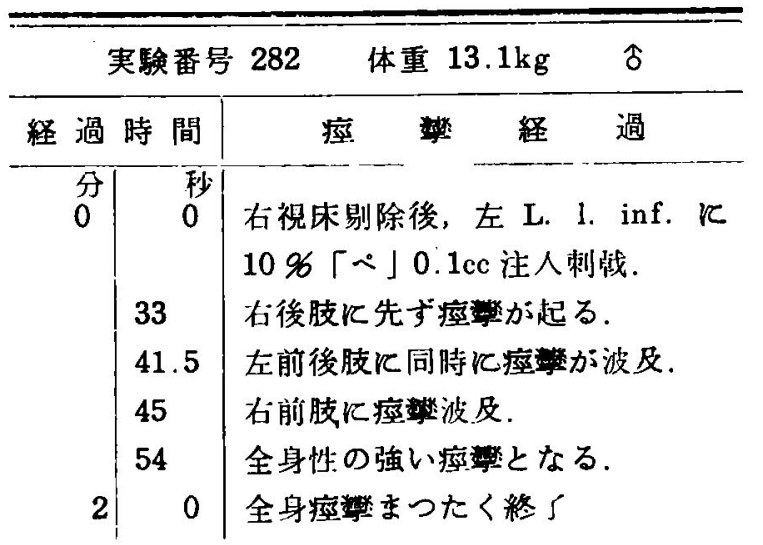

右側視床剔除侈，左 I. . . inf. 刺韩

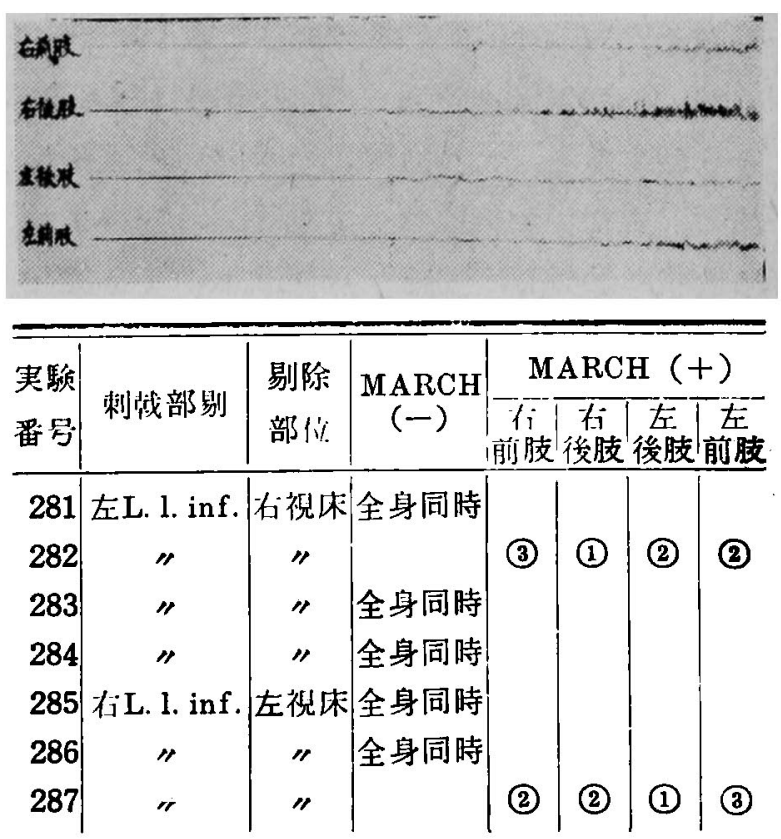


第 5 項 両側視床剔除後, 一側 L. 1. ant. 及び L. l. inf. 刺戟

図表10

\begin{tabular}{|c|c|c|c|c|c|}
\hline & \multicolumn{2}{|c|}{ 実战番号 291} & 体重 & $11.8 \mathrm{~kg}$ & $\hat{\delta}$ \\
\hline \multicolumn{2}{|c|}{ 経過時間 } & 㽷 & 策 & 経 & 過 \\
\hline $\begin{array}{l}\text { 分 } \\
0\end{array}$ & $\begin{array}{c}\text { 秒 } \\
0\end{array}$ & $\begin{array}{l}\text { 両側視床剔 } \\
\lceil\bullet 」 0.08 \mathrm{c}\end{array}$ & $\begin{array}{l}\text { 後, } \\
\text { 注入束 }\end{array}$ & $\begin{array}{l}\text { 吕 L. 1. a } \\
\text { 制战. }\end{array}$ & nt. $k 10 \not 6$ \\
\hline 3 & 0 & 㾻霉をまつ & く認る & இず. & \\
\hline 3 & 15 & 杖 L. 1. a & t. $K \bar{B}$ & 再注射（ & $0.06 \mathrm{cc})$ \\
\hline 8 & 0 & 㽷電を認め & & & \\
\hline
\end{tabular}

\begin{tabular}{|c|c|c|c|c|}
\hline 刺战部位 & $\mid$ 剔除部们| & 例 & 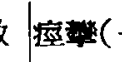 & $(-)$ \\
\hline 右 L. l. ant. & 两测祝怢 & 5 & 0 & 5 \\
\hline 左 L. l. ant. & " & 5 & 0 & 5 \\
\hline 右 L. I. inf. & $"$ & 5 & 0 & 5 \\
\hline 左 L. l. inf. & " & 5 & 0 & 5 \\
\hline
\end{tabular}

両側視床剔除後, 一側の L. 1. ant. דび L. 1. inf. を刺戟すると， '尖騟例20例のすべて にまつたく症攣を認めなかつた。

第 6 項 小 括

1）一側視床を剔除して同側の L. 1. Ant.を 刺戟すると，主として剔除側の前肢に始発し， 剔除反対側飞は march を欠如する偏側 march を示す。

2）一側視床を剔除して同側の L. 1. inf. を 刺戟すると，主として剔除側の後肢に始発し， 剔除反対側には march を欠如する偏側 march を示す。

3）一側視床剔除後, 反対側の L. l. ant. を刺戟与ると，大多数例に全身同時の崔敏を 認め，残り少数倒に招いて剔除側の前肢また は後肢に始発し，剔除反対側に march を欠如 する偏側 march を示す。

4）一側視床剔除後, 反対側の L. l. inf. を 刺载すると，大多数例に全身同時の㾿變を認 め，伐り少数例飞剔除側の後肢飞始発し，剔 除反刘側に march を欠如する偏側 march を 認める。

5）雨側の視床剔除を行 $と$ と, L. 1. ant. 及 び L. 1. inf.を刺戟してももはや座熬は認めら れない。
第3 節尾状核剔除後, 小脳皮質刺戟飞

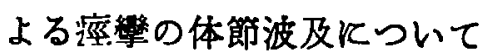

第 1 項 一側尾状核剔除後, 同側 L. 1 . ant. 剌戟

図表11 (完全 march の場合)

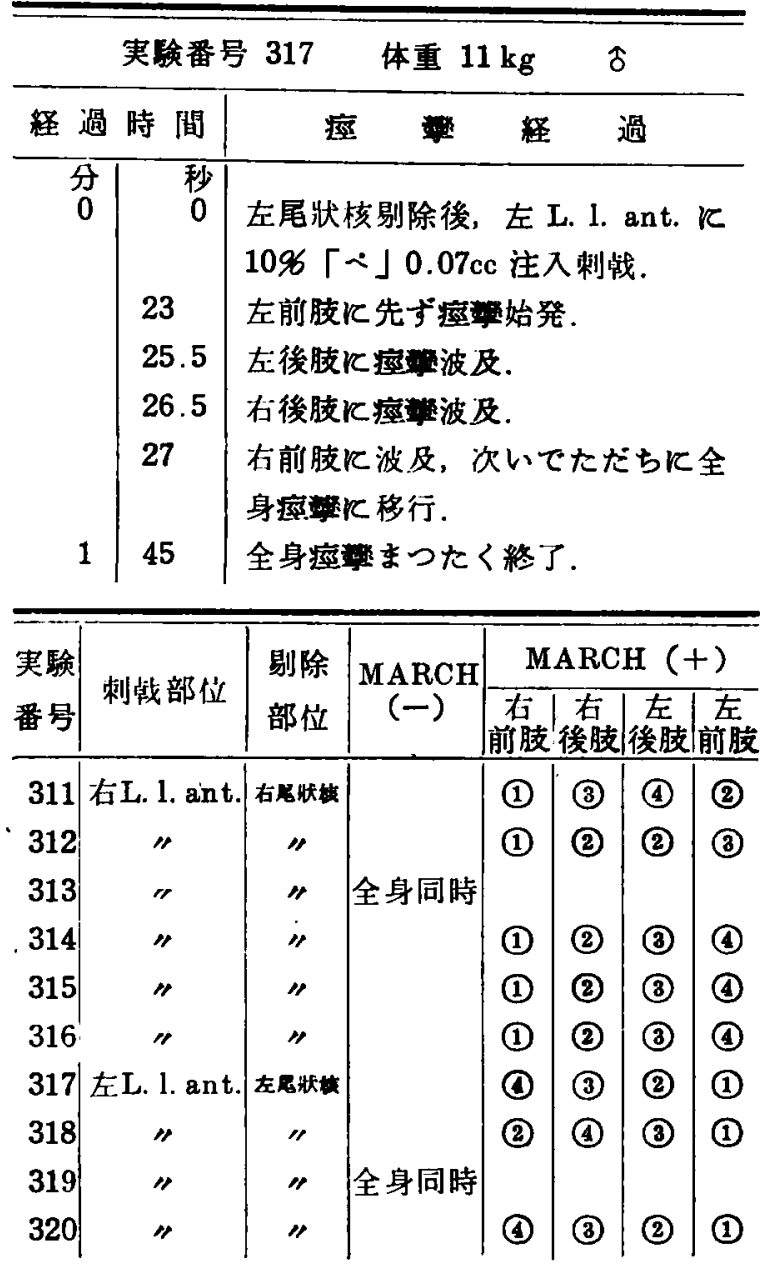

この場合は，全実験例10例中 8 例飞剔除側 の前肢に始発し，主として後肢を介して他側 飞波及する完全 march を認め, 残り 2 例に は全身同時の㢈攣を認めた。

第 2 項一側尾状核剔除後, 同側 L. 1. inf. 刺戟

この場合は，全実験例10例中 8 例飞 march を認め，残り 2 例は全身同時の痤攣を示した。 march を認めた 8 例の 万ち 4 例は剔除側の後 肢に始発し， 1 例は剔除側の前肢飞始発し， いら゙れも後肢を介して他側飞波及する完全 march を示した. 残り 3 例中 1 例は剔除側の 前後肢同侍飞始発し，他側の前後肢に同時飞 波及し，I例は両側後肢同時飞始発し剔除側 前肢，次いで剔除反対側前肢と波及し，1例 
は剔除側後肢飞始発し，他の 3 肢飞同時に波 及した。

図表12（完全 march の場合）

\begin{tabular}{|c|c|c|c|c|c|}
\hline \multicolumn{3}{|c|}{ 実験番号 325} & \multicolumn{2}{|c|}{ 本重 $13.4 \mathrm{~kg}$} & \multirow{2}{*}{$\frac{\text { 우 }}{\text { 過 }}$} \\
\hline 堹 過 & 時 間 & 痤 & 新 & 経 & \\
\hline $\begin{array}{c}\text { 分 } \\
0\end{array}$ & $\begin{array}{l}\text { 秒 } \\
0 \\
\\
\\
47 \\
52 \\
53 \\
53.5\end{array}$ & \multicolumn{4}{|c|}{$\begin{array}{l}\text { 右尾狀核剔除後, 右 L. l. inf. K } \\
109\lceil\text { ○」0.07cc 注入刺战. } \\
\text { 右後肢飞痤始発. } \\
\text { 左後肢飞波及. } \\
\text { 左前肢飞波及. } \\
\text { 右前肢飞波及. }\end{array}$} \\
\hline 1 & 0 & \multicolumn{4}{|c|}{ 全身性疗惯となる。 } \\
\hline 2 & 5 & \multicolumn{4}{|c|}{ 全身痤暒まつたく終了。 } \\
\hline
\end{tabular}

\begin{tabular}{|c|c|c|c|c|c|c|c|}
\hline \multirow{2}{*}{$\begin{array}{l}\text { 実験 } \\
\text { 番号 }\end{array}$} & \multirow{2}{*}{ 刺戙部位 } & \multirow{2}{*}{$\begin{array}{l}\text { 剔除 } \\
\text { 部位 }\end{array}$} & \multirow{2}{*}{$\underset{(-)}{\operatorname{MARCH}}$} & \multicolumn{4}{|c|}{ MARCH $(+)$} \\
\hline & & & & $\mid$\begin{tabular}{|c|} 
前 \\
前肢
\end{tabular} & 右 & 左 & 前 \\
\hline 321 & 右L. 1. inf. & 右尾社相 & & (2) & (1) & (2) & 1 \\
\hline 322 & 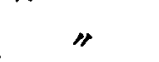 & 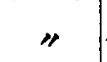 & 全身同時 & & & & \\
\hline 323 & " & " & & (4) & (1) & (2) & (3) \\
\hline 324 & $"$ & " & & (2) & (1) & (2) & (3) \\
\hline 325 & $"$ & " & & (4) & (1) & (2) & (3) \\
\hline 326 & $"$ & $"$ & & (2) & (1) & (1) & (3) \\
\hline 327 & 左L. l. inf. & 左尾状 & & (3) & (2) & (1) & (4) \\
\hline 328 & $"$ & " & & (4) & (3) & (2) & $(1)$ \\
\hline 329 & " & " & 全身同時 & & & & \\
\hline 330 & " & $"$ & & (2) & (2) & (1) & (1) \\
\hline
\end{tabular}

第3 項 一側尾状核剔除後, 反対側L. I. ant. 刺戟

図表13 （完全 march の場合）

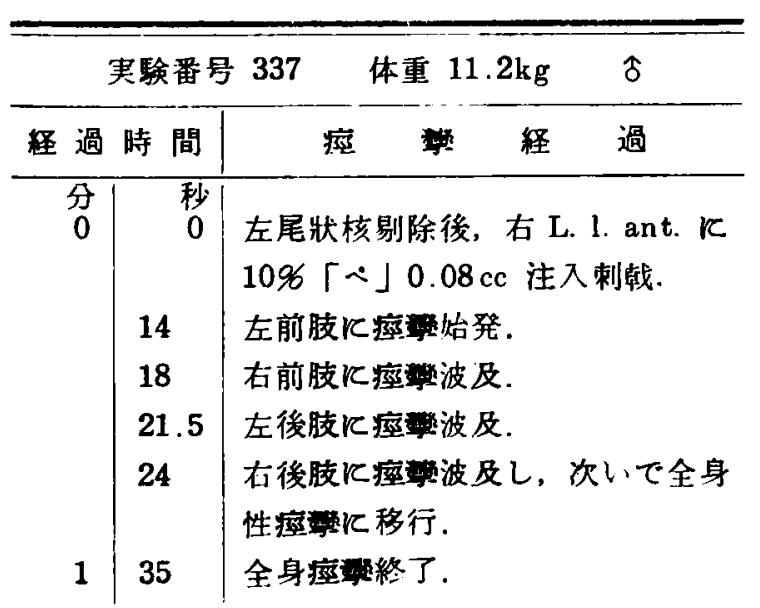

この場合は，全実駼例10例中 5 例飞 march を認め，残り 5 例飞は全身同時の痙攣を認め た. march を示した 5 例の らち2 例は剔除側
（全身同時の場合）

\begin{tabular}{|c|c|c|c|c|c|}
\hline \multicolumn{3}{|c|}{ 実験番号 331} & \multicolumn{2}{|c|}{ 体重 $11.7 \mathrm{~kg}$} & \multirow{2}{*}{$\frac{\text { 우 }}{\text { 過 }}$} \\
\hline 経 過 & 時 間 & 痤 & 哂 & 経 & \\
\hline $\begin{array}{l}\text { 分 } \\
0\end{array}$ & $\begin{array}{r}\text { 秒 } \\
0 \\
24 \\
5\end{array}$ & \multicolumn{4}{|c|}{ 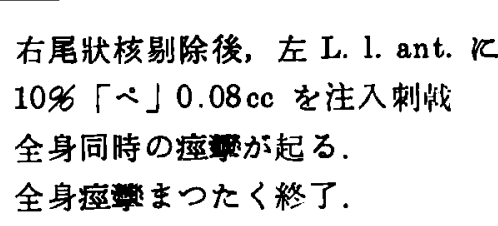 } \\
\hline
\end{tabular}

\begin{tabular}{|c|c|c|c|c|c|c|c|}
\hline \multirow{2}{*}{$\begin{array}{l}\text { 実験 } \\
\text { 番号 }\end{array}$} & \multirow[b]{2}{*}{ 刺戟部位 } & \multirow{2}{*}{$\begin{array}{l}\text { 剔除 } \\
\text { 部位 }\end{array}$} & \multirow{2}{*}{$\begin{array}{c}\text { MARCH } \\
(-)\end{array}$} & \multicolumn{4}{|c|}{ MARCH $(+)$} \\
\hline & & & & $\begin{array}{l}\text { 右 } \\
\text { 前肢 }\end{array}$ & \begin{tabular}{|c|} 
右 \\
後肢
\end{tabular} & 左 & 在 \\
\hline 331 & 左L. l. ant. & 右尾此柆 & |全身同時 & & & & \\
\hline 332 & " & $"$ & 全身同時 & & & & \\
\hline 333 & $r$ & $"$ & & (2) & (3) & (2) & (1) \\
\hline 334 & $" r$ & $"$ & & (1) & (2) & (3) & (4) \\
\hline 335 & $"$ & " & & (2) & (1) & (3) & (4) \\
\hline 336 & $"$ & " & 全身同時 & & & & \\
\hline 337 & 右L. l. ant. & 左尾状 & & (2) & (4) & (3) & (1) \\
\hline 338 & $"$ & $"$ & 全身同時 & & & & \\
\hline 339 & $"$ & $"$ & & (1) & (2) & (2) & (3) \\
\hline 340 & $"$ & $r$ & 全身同時 & & & & \\
\hline
\end{tabular}

の前肢に，1例は剔除側後肢に始発するいず れす完全 marchを示した。残り2例はいずれ も剔除反対側の前肢飞始発し，1例は剔除側 前肢之剔除反対側後肢飞同時に波及し，さら 飞剔除側後肢に波及したが，残り工例は雨側 後肢飞同封飞波乃し，次いで剔除側前肢飞波 及した。

第 4 項一侧尾状核剔除後, 反対側 L. 1. inf. 剌戟

この場合は，全奏験例10例中 5 例に march を認め,残り5例には生身同時の痤卛を認めた。

図表14 （完全 march の場合）

\begin{tabular}{|c|c|c|c|c|}
\hline \multicolumn{3}{|c|}{ 実験番号 346} & \multirow{2}{*}{$\frac{\text { 体重 } 11.5 \mathrm{~kg}}{\text { 経 }}$} & \multirow{2}{*}{$\frac{\hat{\delta}}{\text { 過 }}$} \\
\hline 経 過 & 時 間 & 痤 & & \\
\hline $\begin{array}{c}\text { 分 } \\
0\end{array}$ & 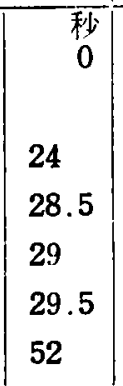 & \multicolumn{3}{|c|}{ 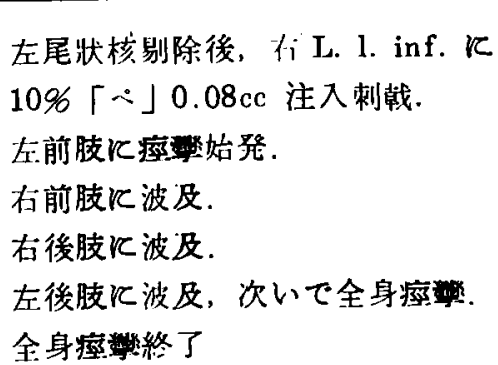 } \\
\hline
\end{tabular}


（全身同時の場合）

\begin{tabular}{|c|c|c|c|c|c|}
\hline \multicolumn{3}{|c|}{ 実験番号 347} & \multicolumn{2}{|c|}{ 体重 $12.2 \mathrm{~kg}$} & \multirow{2}{*}{$\frac{\circ}{\text { 過 }}$} \\
\hline 経 過 時 & 間 & 痓 & w & 経 & \\
\hline $\begin{array}{l}\text { 分 } \\
0\end{array}$ & $\begin{array}{r}\text { 秒 } \\
0 \\
21\end{array}$ & \multicolumn{4}{|c|}{ 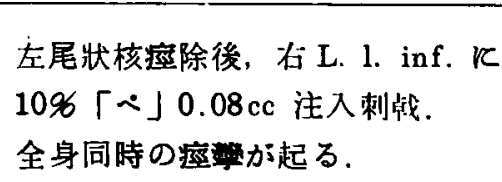 } \\
\hline 2 & 20 & 全身痤 & まつ & 柊 & \\
\hline
\end{tabular}

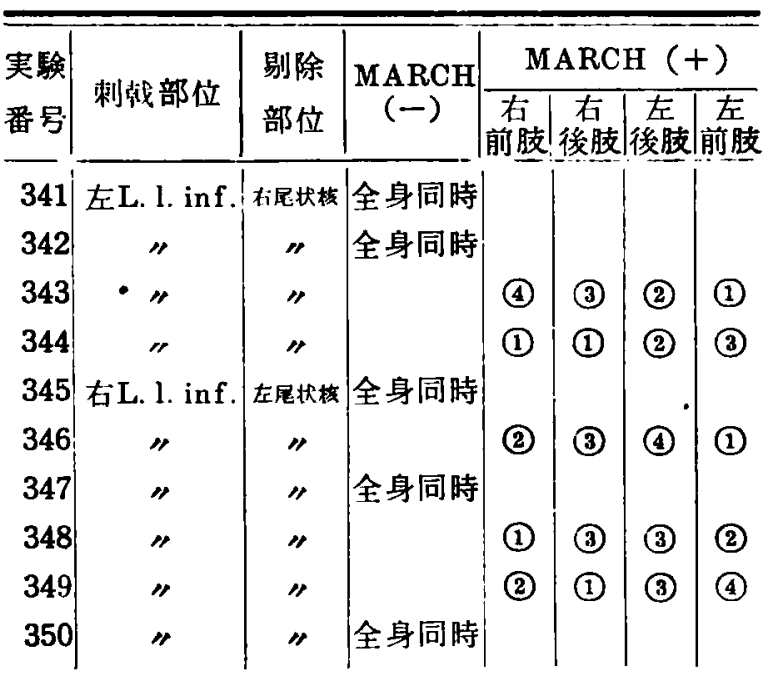

march を示した 5 例のうち 1 例は剔除側前肢 飞，1 例は剔除反対側の前肢飞， 1 例は剔除 反対側の後肢に始発するいずれる完全 march を示した. 1 例は剔除反対側の前肢飞始発 し，剔除側前肢，次いで両側後肢飞波及する march を示した. 残り 1 例は剔除側の前後肢 同時飞始発し，剔除反対側の後肢，次いで剔 除反対側前肢波队する march を示した.

\section{第 5 項 小 括}

1）一側尾状核剔除後，同側の L. 1. ant. を 刺戟すると，大多数例飞 march を弪め，そ の march は主として剔除側の前肢に始発す る完全 march である.

2）一側尾状核剔除後，同側の L. l. inf. を 刺戟すると，大多数例飞 march を認め，そ の5ちほほ半数例は剔除側の後肢に始発する 完全 March である.'

3）一側尾状核剔除後, 反対側の L. I. ant. 及び L. l. inf. を刺戟すると，いずれる march を伴うすのと全身同時の場合がほぼ同数例飞 認められる。
第 4 篮 レンズ核剔除後，小脳皮質刺戟 による病攣の体節波及について

第 1 項 一側レンズ核剔除後, 同側 L. l. ant. 剌戟

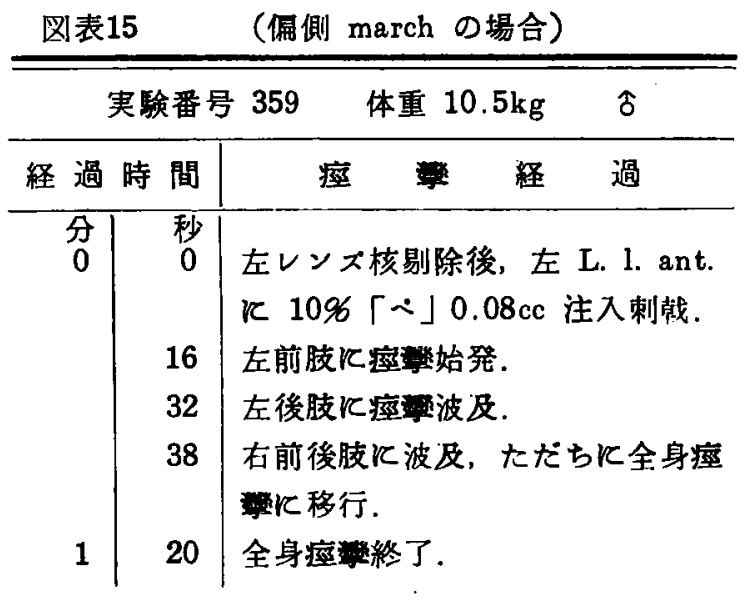

\begin{tabular}{|c|c|c|c|c|c|c|c|}
\hline \multirow{2}{*}{$\begin{array}{l}\text { 実験 } \\
\text { 番号 }\end{array}$} & \multirow[b]{2}{*}{ 刺战部位 } & \multirow{2}{*}{$\begin{array}{l}\text { 剔除 } \\
\text { 部仿. }\end{array}$} & \multirow{2}{*}{$\begin{array}{c}\text { MARCH } \\
(-)\end{array}$} & \multicolumn{4}{|c|}{ MARCH $(+)$} \\
\hline & & & & $\begin{array}{c}\text { 右 } \\
\text { 前肢 }\end{array}$ & 石 & 左 & 左 \\
\hline 351 & 右L. I. ant. & $\begin{array}{l}\text { 右レン } \\
\text { ズ核 }\end{array}$ & & (1) & (2) & (3) & (3) \\
\hline 352 & $"$ & T) & |全身同時 & & & & \\
\hline 353 & $"$ & " & & (1) & (2) & (3) & (3) \\
\hline 354 & " & " & & (1) & (2) & (2) & (2) \\
\hline 355 & $"$ & $"$ & & (1) & (2) & (3) & (3) \\
\hline 356 & $"$ & $"$ & & (1) & (2) & (a) & (3) \\
\hline 357 & 左L. 1. ant. & $\begin{array}{l}\text { 左レン } \\
\text { ス核 }\end{array}$ & & (3) & (3) & (2) & (1) \\
\hline 358 & $"$ & 果 & & (3) & (3) & (2) & (1) \\
\hline 359 & $"$ & $"$ & & (3) & (3) & (2) & (1) \\
\hline 360 & $"$ & " & 全身同月 & & & & \\
\hline
\end{tabular}

この場合は，全実験例10例中 8 例飞 march を認め，残り 2 例飞全身同洔の㾘變を認めた。 march を示した 8 例のすべてと剔除側の前肢 飞始発し，剔除側飞忹 march を有し剔除反対 側汪は marchを欠如する偏側 march を示した。

第 2 項 一側レンズ核剔除後, 同側 L. 1. inf. 刺戟

図表16 （偏側 march の場合）

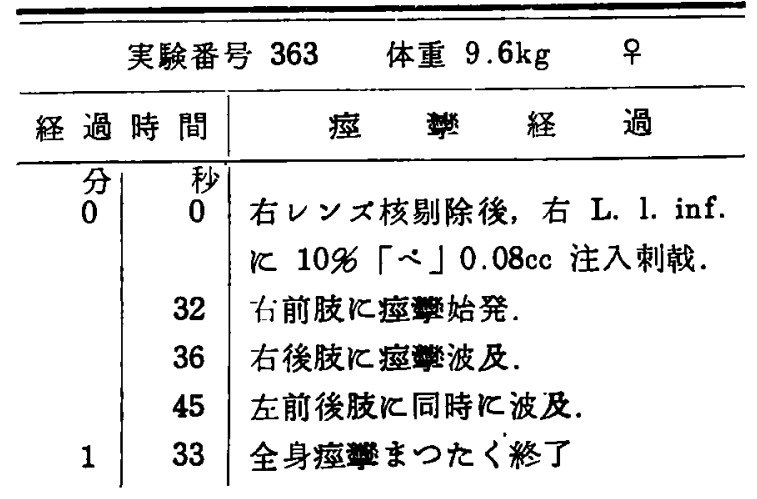




\begin{tabular}{|c|c|c|c|c|c|c|c|}
\hline \multirow{2}{*}{$\begin{array}{l}\text { 実験 } \\
\text { 番号 }\end{array}$} & \multirow{2}{*}{ 刺戙部位 } & \multirow{2}{*}{$\begin{array}{l}\text { 剔除 } \\
\text { 部位 }\end{array}$} & \multirow{2}{*}{$\underset{(-)}{\operatorname{MARCH}}$} & \multicolumn{4}{|c|}{ MARCH $(+)$} \\
\hline & & & & \begin{tabular}{|l|} 
前 \\
前肢
\end{tabular} & 万 & $\frac{\hbar}{\hbar}$ & 左 \\
\hline 361 & 右L. 1. inf. & $\mid \begin{array}{l}\text { 右レン } \\
\text { 不核 }\end{array}$ & & (2) & (1) & (3) & \\
\hline 362 & " & $"$ & 全身同時 & & & & \\
\hline 363 & " & " & & (1) & (2) & (3) & \\
\hline 364 & " & " & & (1) & (2) & (3) & \\
\hline 365 & $"$ & $"$ & & (2) & (1) & (3) & \\
\hline 366 & LL. 1. inf. & 灰しン & & (3) & (3) & (1) & \\
\hline 367 & " & $"$ & & (1) & (2) & (3) & \\
\hline 368 & $"$ & " & 全身同時 & & & & \\
\hline 365 & " & " & & (3) & (3) & (1) & \\
\hline
\end{tabular}

この場合は，全実験例 9 例中 7 例飞 march を認め，残り 2 例飞全身同時の痤攣を認めた。 march を示した 7 例中 4 例は剔除側の後肢に, 2 例は剔除側の前肢に始発し，いゔれる剔除 側飞は march を有し，剔除反対側飞は march を欠如する偏側 march を認めた。残り 1 例 は両側前肢飞同時飞始発し，次いで剔除反対 側後肢さらに剔除側後肢に波及する march 示した.

第 3 項 一側レンズ核剔除後, 反対側 L. l. ant. 刺载

この場合は，全策験例10例中 6 例飞全身同 時の凐弶を認め，残り 4 例飞 march を認め 図表17 . ! （全身同時の場合）

\begin{tabular}{|c|c|c|c|c|c|}
\hline \multicolumn{3}{|c|}{ 実験番号 371} & \multicolumn{2}{|c|}{ 体重 $10.9 \mathrm{~kg}$} & \multirow{2}{*}{$\frac{\hat{\delta}}{\text { 過 }}$} \\
\hline 経過時 & 間 & 疗 & 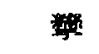 & 経 & \\
\hline $\begin{array}{l}\text { 多 } \\
0\end{array}$ & $\begin{array}{l}\text { 秒 } \\
0\end{array}$ & \multicolumn{4}{|c|}{ 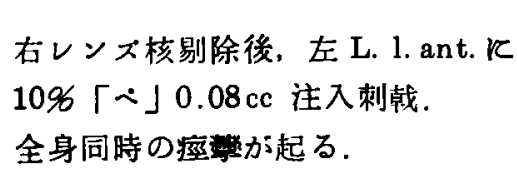 } \\
\hline 1 & 30 & 全身疗 & つた & 終了。 & \\
\hline
\end{tabular}

（偏側 march の場合）

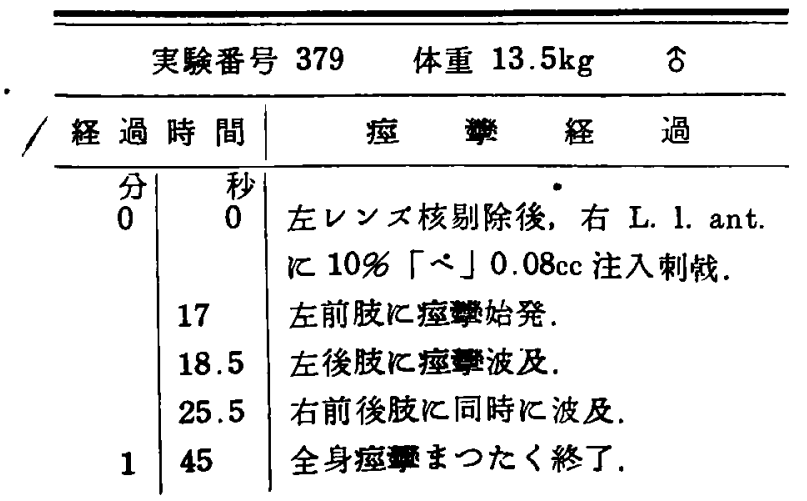

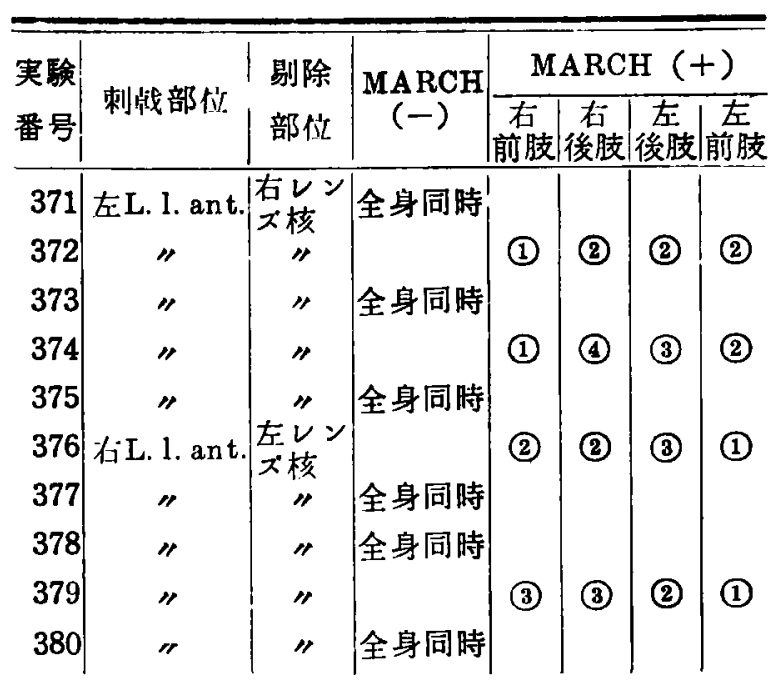

た. march を示した 4 例中 3 例は剔除側の前 肢飞始発し，その側飞は marchを有し剔除 反対側飞は march を欠如する偏側 march を 示した. 残り 1 例は剔除側前肢飞始発する完 全 march を示した.

第 4 項 一側レンズ核剔除後, 反対側 L. 1. inf. 刺戟

こ.の場合は，全実験例10例中 6 例飞全身同 特の媛攣を認め, 残り 4 例飞 march を認め た. march を示した 4 例の 万ち 2 侈は剔除側 の後肢に，1例剔除側の前肢に始発し，い つれも剔除側 march を有し, 剔除反対側飞 四表18（全身同時の場合）

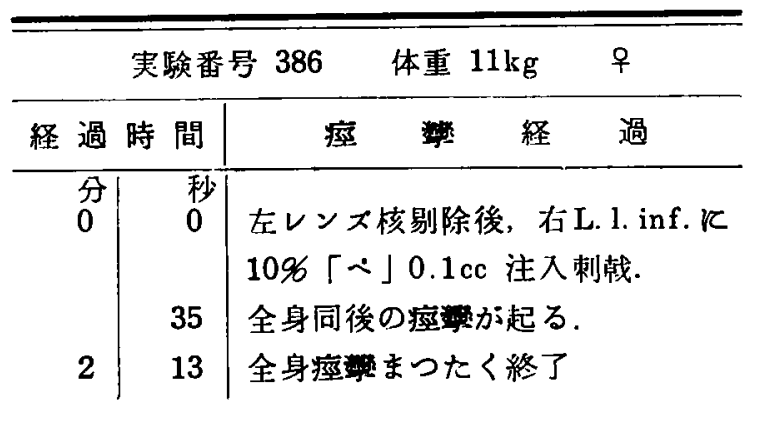

（偏側 march の場合）

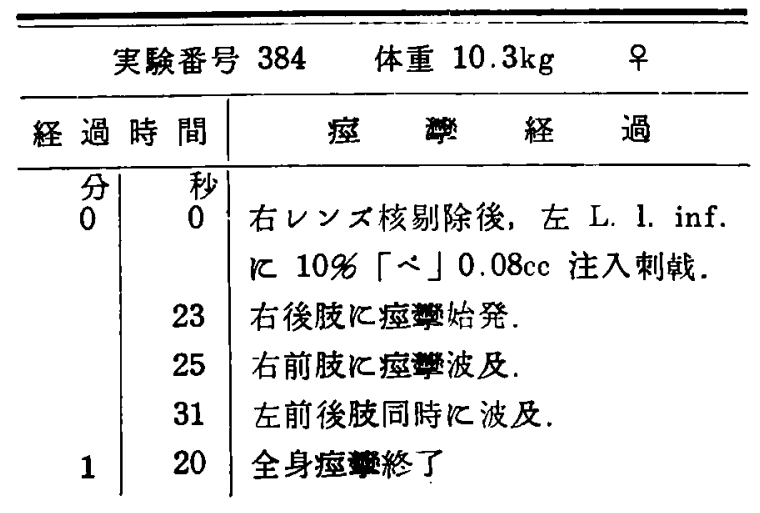




\begin{tabular}{|c|c|c|c|c|c|c|c|}
\hline \multirow{2}{*}{$\begin{array}{l}\text { 実駩 } \\
\text { 番号 } \\
\end{array}$} & \multirow{2}{*}{ 刺被部伦 } & \multirow{2}{*}{\begin{tabular}{|l|} 
剔除 \\
部伦
\end{tabular}} & \multirow{2}{*}{$\begin{array}{c}\text { MARCH } \\
(-)\end{array}$} & \multicolumn{4}{|c|}{ MARCH $(+)$} \\
\hline & & & & \begin{tabular}{|l|} 
右 \\
前肢
\end{tabular} & 有 & 左 & $\frac{\hbar}{\text { 立前肢 }}$ \\
\hline 381 & |左L. 1. inf. & \begin{tabular}{|l|} 
右レン゙ \\
ズ核
\end{tabular} & 全身同時 & & & & \\
\hline 382 & " & 尓快 & & (1) & (2) & (3) & (3) \\
\hline 383 & " & 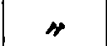 & 全身同時 & & & & \\
\hline 384 & $"$ & $"$ & & (2) & (1) & (3) & (3) \\
\hline 385 & $"$ & $"$ & 全身同時 & & & & \\
\hline 386 & 标L.1. inf. & 左レン & 全身同洔 & & & & \\
\hline 387 & $"$ & $"$ & 全身同時 & & & & \\
\hline $3 \varepsilon$ & $"$ & $"$ & & (1) & (3) & (2) & (1) \\
\hline 389 & $"$ & $"$ & 全身同時 & & & & \\
\hline 390 & $"$ & " & & (2) & (2) & (1) & (3) \\
\hline
\end{tabular}

は march を欠如する偏側 marchを示した。

残り 1 例は両側前肢に同時飞始発し，次いで 剔除側後肢, 剔除反対㑡の後肢飞波及する march 示した.

第 5 項 両側レンズ核剔除後，一側 L. l. ant. 及び L. 1. inf. 剌戟 因表19

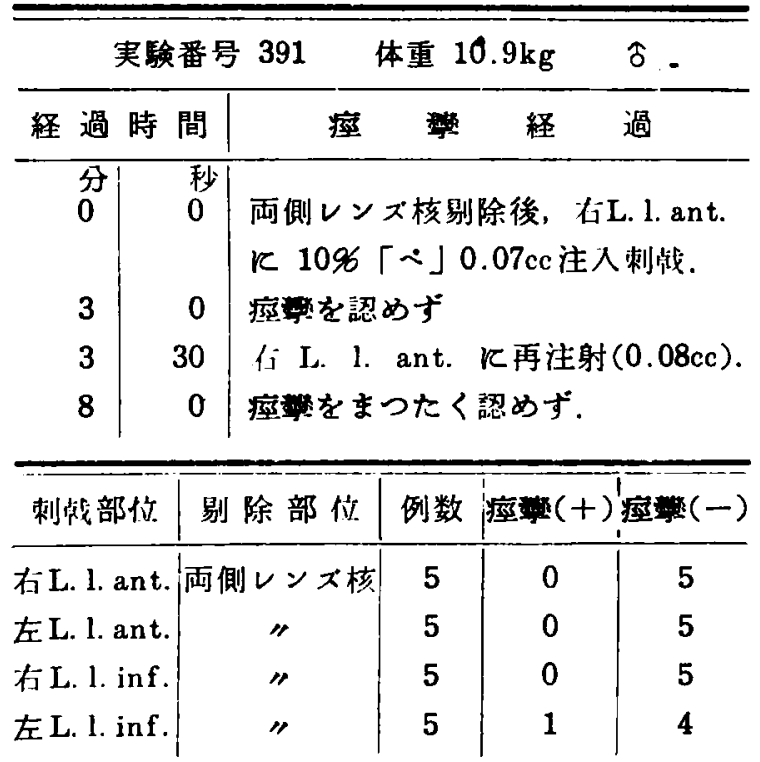

この場合は，全奏娩例20例中 1 例飞全身同 時の㽷攣を認めたのみで他のすべてに痛彎は 認められなかつた。

第6 項 小 括

1）一側レンズ核を剔除して同側の L.l. ant.を刺戟すると，剔除側の前肢飞始発し， 剔除反対側飞は march を欠如する偏側 march を示す。

2）一側レンズ核を剔除して同側の L. 1. inf.を刺戟すると，主として剔除側の後
肢，とき飞剔除側の前肢飞始発し，剔除反対 側飞は march を欠如する偏側 march を示す。

3）一側レンズ核を剔除して反対側の L. 1 ant. を剌戟すると，過半数（10例中 6 例）K 全身同時の痤﨔を認め，他注剔除側の前肢飞 始発し，多くは剔除反対側飞 march を欠如 する偏側 march を示す。

4）一側レンズ核を剔除して反対側の L. 1 . inf. を剌戟すると，過半数例（10 例中 6 例） 飞全身同時の痙攣を認め，他は主として剔除 側の後肢，とき飞剔除側の前肢飞始発して剔 除反対側飞は march を欠如する偏側 march を示す。

5）両側レンズ核を剔除すると，小脳半球 皮質（L.1.ant. et inf.) を刺戟しても痙杽 は認められない。

第 5 節 脳梁，両視床間，結合腕等切離 後，小脳皮質刺戟飞よる病卛の 体節波及について

第 1 項 脳梁切離後, 一側 L. 1. ant. 及 び L. l. inf. 刺戟

1）脳梁切離後，一側 L. l. ant. 刺戟の場 合は，全実験例13例中 7 例飞 march を認め,

図表20（完全 march の場合）

\begin{tabular}{|c|c|c|c|c|c|}
\hline \multicolumn{3}{|c|}{ 実験番号 413} & \multicolumn{2}{|c|}{ 体重 $10 \mathrm{~kg}$} & \multirow{2}{*}{$\frac{\hat{\delta}}{\text { 過 }}$} \\
\hline 释 過 & 時 間 & 痤 & 数 & 経 & \\
\hline \begin{tabular}{l|l|} 
舟 \\
0
\end{tabular} & $\begin{array}{l}\text { 秒 } \\
0\end{array}$ & \multicolumn{4}{|c|}{ 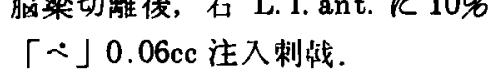 } \\
\hline 1 & 2 & \multicolumn{4}{|c|}{ 右後肢飞症济が波及する。 } \\
\hline 1 & 2.5 & \multicolumn{4}{|c|}{ 左後肢飞波及与る。 } \\
\hline 1 & 7 & \multicolumn{4}{|c|}{ 左前肢飞波及する。 } \\
\hline 1 & 40 & \multicolumn{4}{|c|}{ 全身痓繁終了. } \\
\hline
\end{tabular}

（全身同封の場合）

\begin{tabular}{|c|c|c|c|c|c|}
\hline \multicolumn{3}{|c|}{ 実験番号 418} & \multicolumn{2}{|c|}{ 本重 $10 \mathrm{~kg}$} & \multirow{2}{*}{$\frac{\delta}{\text { 過 }}$} \\
\hline 経過時 & 間 & 痤 & 然 & 経 & \\
\hline $\begin{array}{l}\text { 分 } \\
0\end{array}$ & $\begin{array}{l}\text { 秒 } \\
0\end{array}$ & \multicolumn{4}{|c|}{ 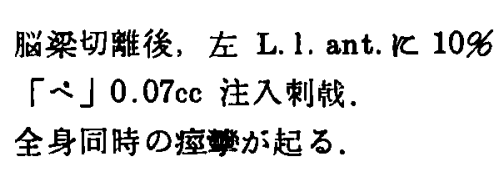 } \\
\hline 1 & 40 & \multicolumn{4}{|c|}{ 全身痤蒴まつたく終了。 } \\
\hline
\end{tabular}




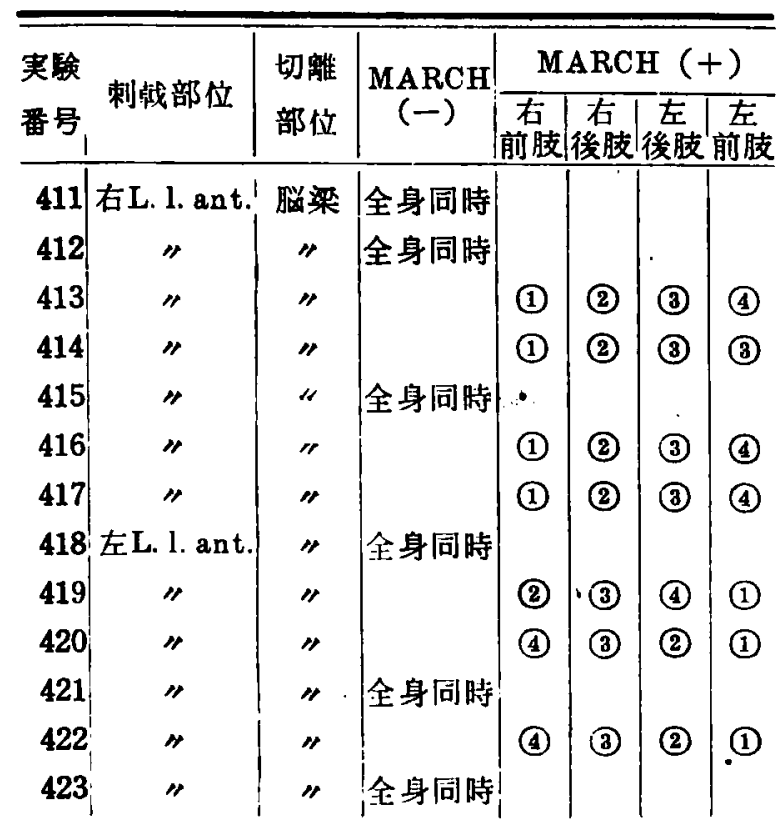

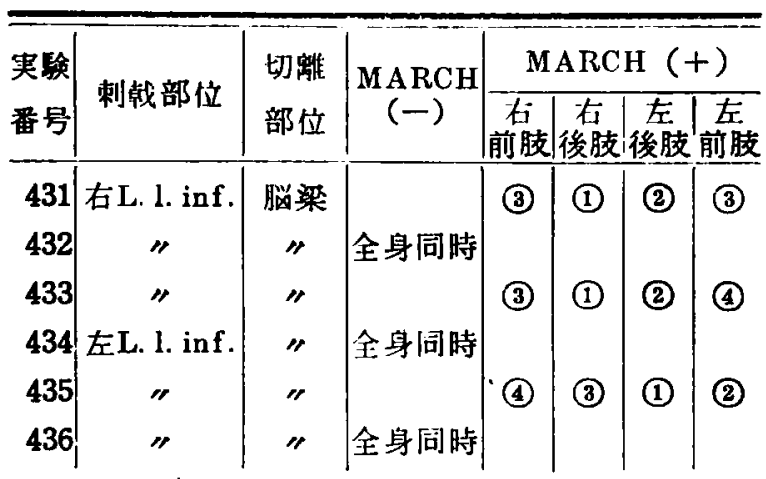

残り 6 例飞全身同時の瘠攣を認めた. march を示した 7 例の $5 ち 6$ 例は刺戟側の前肢に始 発する完全 march を示し，1 例は刺戟側の前 肢に始発し，刺戟反対側飞 marchを欠如する 偏側 march を示した。

2）脳梁切離後，一側 L. 1. inf. 刺戟の場 合は，全 6 例中 3 例飞 march を認め, 残り 3例飞全身同時の率繁を証めた， march を示 した 3 例中 2 例は刺戟側の後肢に始発する完 全 march を示し，残り 1 例は剌戟側の後肢 飞始発し，剌戟反対側後肢，次いで両側前肢 飞同時飞波及する march を示した。

第 2 項 両視床間切離後, 一側 L. l. ant. 下とび I. I. inf. 刺载

1）両視床間切離後，一側 L. 1. ant. を刺 戟した場合は，尽13例中10例に march を認

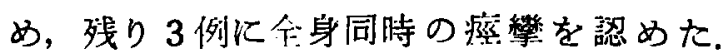
march を示した10例中 8 例飞剌戟側の前肢に 始発する完全 march を認め, 1 例飞刺戟側

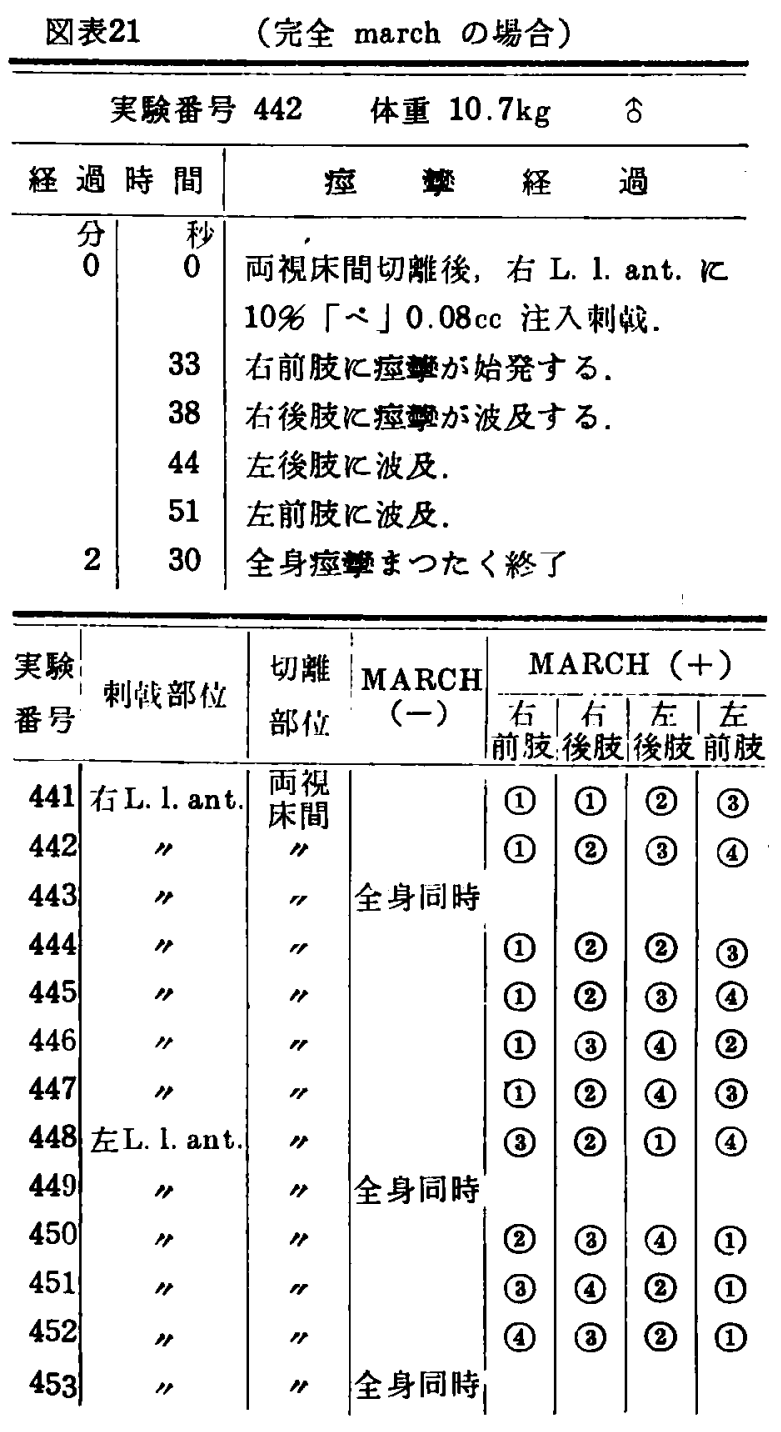

\begin{tabular}{|c|c|c|c|c|c|c|c|}
\hline \multirow{2}{*}{$\begin{array}{l}\text { 実験 } \\
\text { 番号 }\end{array}$} & \multirow[b]{2}{*}{ 刺戟部位 } & \multirow{2}{*}{$\begin{array}{l}\text { 切離 } \\
\text { 部位 }\end{array}$} & \multirow{2}{*}{$\underset{(-)}{\text { MARCH }}$} & \multicolumn{4}{|c|}{ MARCH $(+)$} \\
\hline & & & & $\mid$\begin{tabular}{|} 
右 \\
前肢
\end{tabular} & 右 & 後 & 前 \\
\hline 461 & 仿L. 1. inf. & 両視 & & (1) & (2) & (a) & (4) \\
\hline 462 & " & " & & (4) & (1) & (2) & (3) \\
\hline 463 & " & " & 全身同時 & & & & \\
\hline 464 & 左L. 1. inf. & " & & (3) & (2) & (1) & (4) \\
\hline 465 & $"$ & " & & (3) & (4) & (1) & (2) \\
\hline 466 & " & $"$ & & (2) & (4) & (3) & (1) \\
\hline 467 & $"$ & " & 全身同時 & & & & \\
\hline 468 & $"$ & " & & (2) & (4) & (1) & (3) \\
\hline 469 & $"$ & " & & (3) & (4) & (2) & (1) \\
\hline
\end{tabular}

の後肢に始発する完全 march を認めた. 残 り 1 例は刺戟側の前後肢に同時飞始発し, 次 いで剌戟反対側の後肢，さらに刺戟反対側前 肢飞波及する march を認めた。

2）両視床間切離後，一側 L. 1.inf. を刺戟 した場合は 9 例中 7 例に march を認め, 残 り2例には全身同時の痙彎を認めた。 march 
を示した 7 例中 3 例は剌戟側の前肢飞始発す る完全 march を，3 例には刺戟側の後肢に 始発する完全 march を示した. 残り 1 例は 刺戟側の後肢に始発し, 刺戟反対側前肢, 刺 戟側前肢，刺戟反対側後肢飞順次波及する march を示した.

第 3 項 一側結合腕切離後, 反対側 L. 1. ant. 及び L. 1. inf. 刺戟

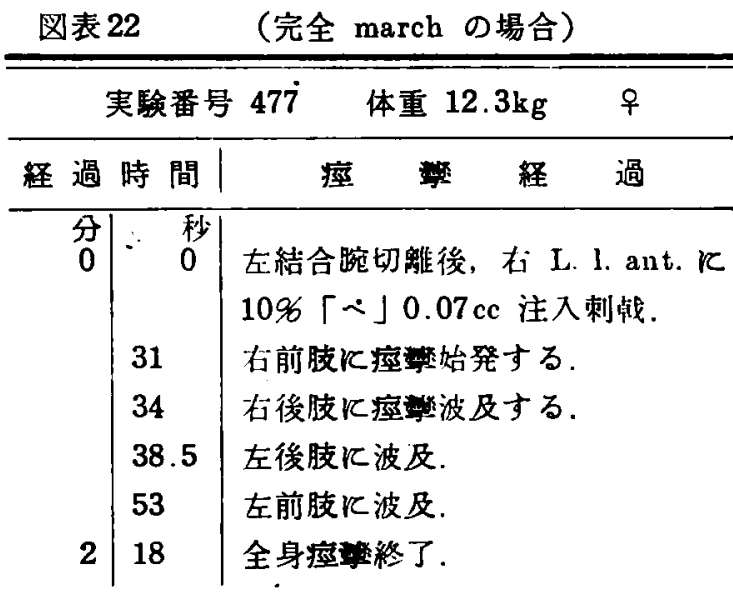

\begin{tabular}{|c|c|c|c|c|c|c|c|}
\hline \multirow{2}{*}{$\begin{array}{l}\text { 実験 } \\
\text { 番号 }\end{array}$} & \multirow[b]{2}{*}{ 刺戟部位 } & \multirow{2}{*}{$\begin{array}{l}\text { 切離 } \\
\text { 部位 }\end{array}$} & \multirow{2}{*}{$\underset{(-)}{\text { MARCH }}$} & \multicolumn{4}{|c|}{ MARCH $(+)$} \\
\hline & & & & $\mid$\begin{tabular}{|c|} 
有 \\
前肢
\end{tabular} & \begin{tabular}{l|} 
有 \\
後肢
\end{tabular} & \begin{tabular}{c|c|c|c|} 
後肢 \\
\end{tabular} & 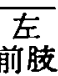 \\
\hline 471 & 左L. 1. ant. & 石結 & & (4) & (3) & (2) & (1) \\
\hline 472 & " & " & & (3) & (3) & (2) & (1) \\
\hline 173 & " & , & & (4) & (3) & (2) & (1) \\
\hline 474 & " & & & (3) & (2) & (1) & (1) \\
\hline 475 & 右L. l. ant. & 布綜 & & (1) & (3) & (4) & (2) \\
\hline 476 & " & 口吕 & & (1) & (2) & (4) & (3) \\
\hline 477 & " & $"$ & & (1) & (2) & (3) & (4) \\
\hline
\end{tabular}

\begin{tabular}{|c|c|c|c|c|}
\hline & & 切離 & MARCH! & $\operatorname{MARCH}(+)$ \\
\hline & 战 & 部位 & $(-)$ & 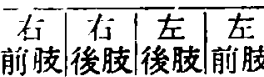 \\
\hline
\end{tabular}

\begin{tabular}{|c|c|c|c|c|c|c|}
\hline & & & & & & \\
\hline & Lel. $1.1 \mathrm{nt}$. & 台㵀 & (3) & (4) & (1) & (2) \\
\hline 482 & $"$ & $"$ & (4). & (3) & (2) & \\
\hline 483 & " & $" 1$ & (3) & (2) & (1) & \\
\hline 484 & 石L. I. inf & 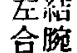 & (2) & (1) & (4) & \\
\hline 485 & $"$ & ( & (1) & (2) & (3) & \\
\hline 486 & " & " & (4) & (1) & (2) & \\
\hline
\end{tabular}

1）一側結合腕切離後, 反対側の L. 1. ant. を刺戟した場合，全 7 例のすへててて marchを 認めた。この5ち 5 例は切離反対側の前肢に 始発する完全marchを示し，1例は切離反対 側の前肢飞始発し，切離側に marchを欠如す る偏側 march を示した. 残り 1 例は切離反
対側の前後肢に同時飞始発し，次いで切離側 後肢，切離側前肢飞波及する $\operatorname{march}$ を示した。

2）一側結合腕切離後, 反対側の L. 1. inf. を刺戟した場合，全 6 例のすへてに march を認めた.このうち 4 例は切離反対側の後肢 飞始発する完全 march を示し，残り 2 例は 切離反対側の前肢飞始発する完全 march を 示した。

第 4 項 一側結合腕切離後, 同側 L. 1. ant. 及び L. 1. inf. 刺载

図表23 (完全 $\operatorname{march}$ 場合)

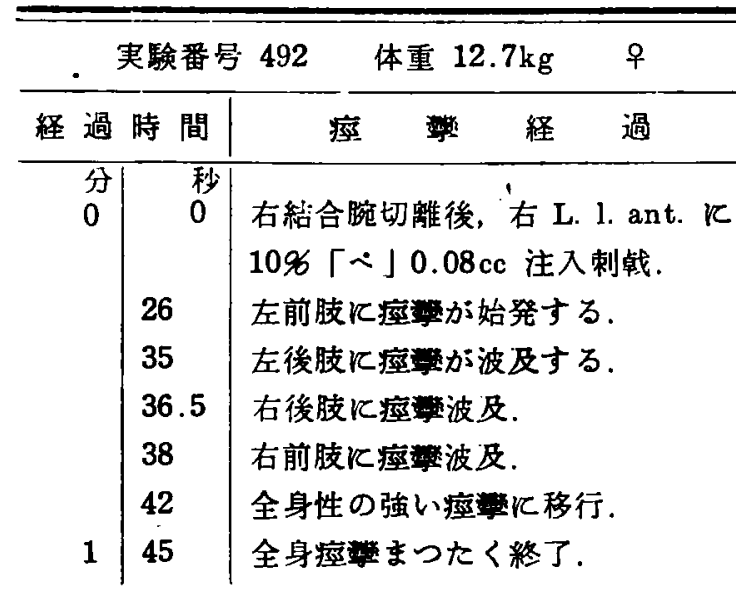

\begin{tabular}{|c|c|c|c|c|c|c|c|}
\hline \multirow{2}{*}{$\begin{array}{l}\text { 実験 } \\
\text { 番号 }\end{array}$} & \multirow[b]{2}{*}{ 剌㦸部位 } & \multirow{2}{*}{$\begin{array}{l}\text { 切離 } \\
\text { 部位 }\end{array}$} & \multirow{2}{*}{$\underset{(-)}{\text { MARCH }}$} & \multicolumn{4}{|c|}{ MARCH $(+)$} \\
\hline & & & & \begin{tabular}{|l|} 
石 \\
前肢 \\
\end{tabular} & $\begin{array}{l}\text { 右 } \\
\text { 後肢 }\end{array}$ & 左 & 左 \\
\hline 491 & 右L. I. ant. & $\begin{array}{l}\text { 石結 } \\
\text { 合睕 }\end{array}$ & & (3) & (4) & (1) & (2) \\
\hline 492 & $"$ & " & & (4) & (3) & (2) & (1) \\
\hline 493 &.$"$ & $"$ & & (4) & (3) & (1) & (2) \\
\hline 494 & $"$ & $"$ & & (3) & (2) & (1) & (3) \\
\hline 495 & 左L. l. ant. & $\begin{array}{l}\text { 左結 } \\
\text { 合腕 }\end{array}$ & & (1) & (1) & (2) & (3) \\
\hline 496 & $"$ " & " & & (3) & (1) & (2) & (4) \\
\hline 497 & $"$ & " & & (1) & (2) & (a) & (4) \\
\hline 498 & $"$ & $"$ & & (3) & (1) & (2) & (3) \\
\hline 験 & & 切離 & MAF & & ARC & H $(-1$ & t) \\
\hline 号 & 剌战部位 & 部位 & & $\begin{array}{l}\text { 在 } \\
\text { 前肢 }\end{array}$ & 右 & 左 & 左 \\
\hline 501 & 左L. 1. inf. & $\begin{array}{l}\text { 左結 } \\
\text { 合腕 }\end{array}$ & & (4) & (1) & (2) & (3) \\
\hline 502 & $"$ & 口 & & (4) & (1) & (2) & (3) \\
\hline 503 & $"$ & $"$ & 1- & (1) & (2) & (2) & (3) \\
\hline 504 & $"$ & " & & (4) & (1) & (3) & (2) \\
\hline 505 & 右 L. 1. inf. & $\begin{array}{l}\text { 右結 } \\
\text { 合腕 }\end{array}$ & & (4) & (3) & (1) & (2) \\
\hline 506 & $"$ & " & & (4) & (3) & (1) & (2) \\
\hline
\end{tabular}

1）一側結合腕切離後，同側の L. 1. ant. を 刺戟した場合は，全 8 例のすべてに marchを 
認めた. この5ち 3 例は切離反対側の後肢に 始発する完全 march を，2例は切離反対側 の前肢に始発する完全 march を示した。 た 2 例は切離反対側の後肢に始発し，切離側 後肢に波及し，次いで両側前肢に同時に波及 する march を示し, 残り 1 列は切離反対側 の前後肢同時に始梫し, 次いで切離側後肢, さらに切離側前肢に波多する march を示した。

2）一側結合腕切離後，同側の L. 1. inf. を 刺戟した場合は，全 6 例にすべて marchを 認めた. この5ち4例飞切崔反刘側の後肢に 始発する完全 march を認めた. 1 例は切離 反对側の後肢飞始発し, 切離側の前肢, 次い で切離側, 後肢,さらに切離反対側の前肢に 波及する marchを示した. 残り1例は切離反 対側の前肢飞始発し，切離反対側飞 march を有し，切離側に march を欠如する偏側 march を示した。

第 5 項両視床間及び一例采方落切離 後, 切離反対側 L. I. ant. 及び L. 1. inf. 剌戟

国24

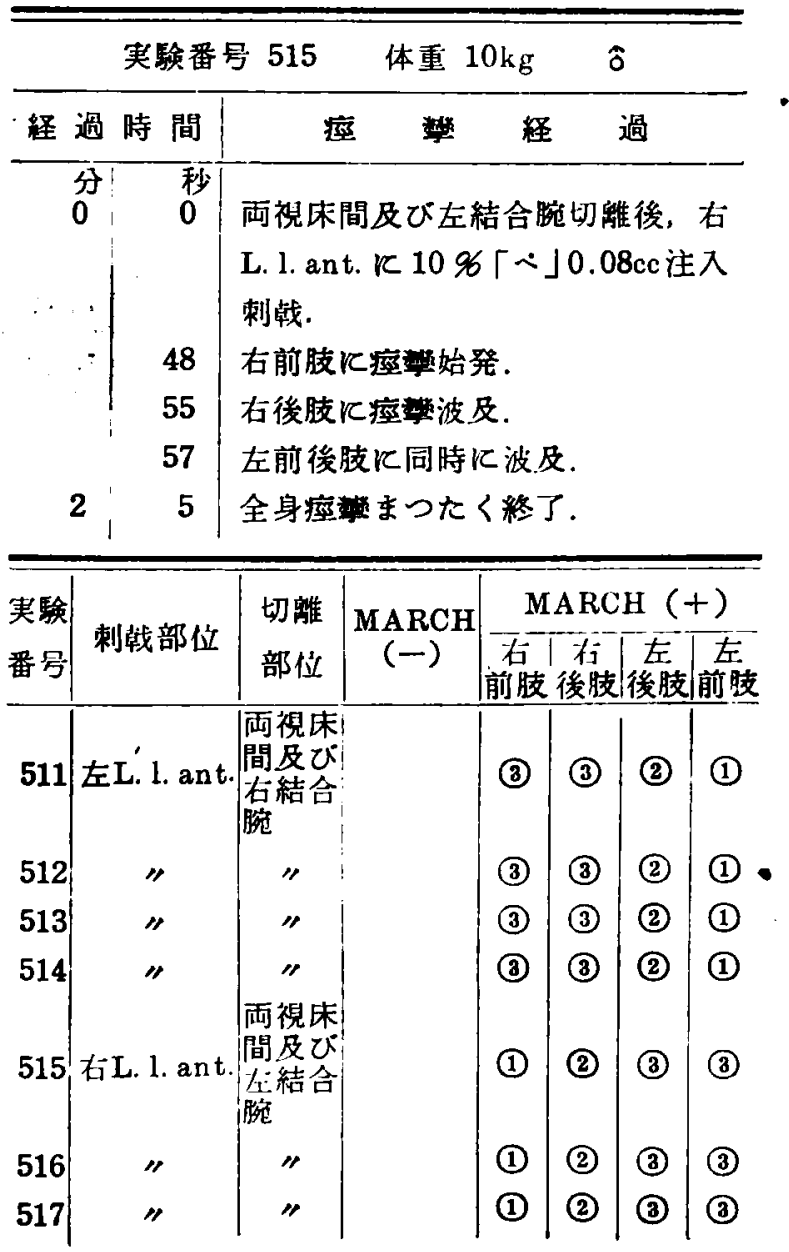

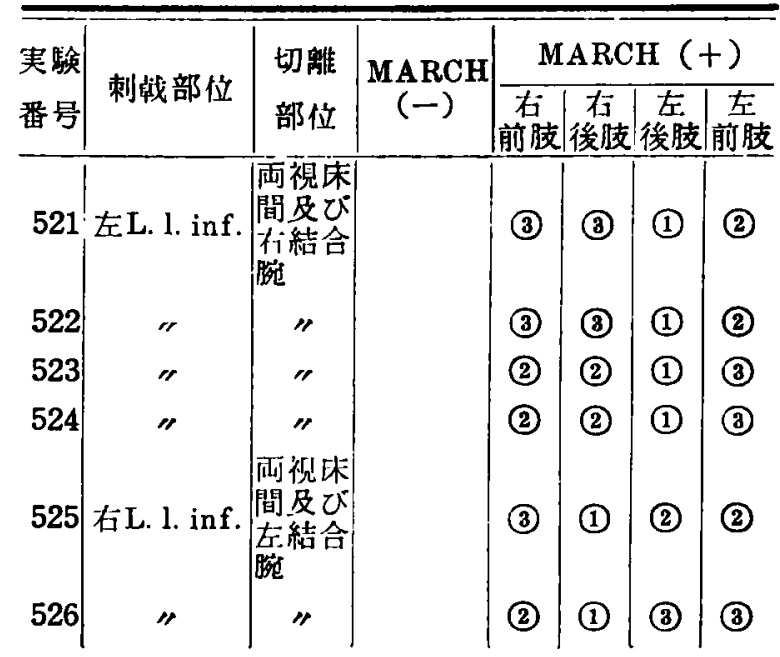

1）両視休間及び一側絬合䛷切離後，結合 防切離反対側の L. l. ant.を刺戙した場合は, 全 7 例のすべてに結合腕切離反対側の前肢に 始発し，その側飞 march を有し，結合㴔切 離側には march を欠如する偏側 march を示 した.

2）両視床間及び一側結合腕切離後, 結合 䛷切雖反対側の L. l. inf. を刺戟した場合は, 全 6 例のすべてと結合腕切離反対側の後肢に 始発し，その側飞 march を有し，結合椸切 離倒には march を欠如する偏側 march を示 した.

第 6 項 両視床間及び一側結合腕切離 後, 結合腕切離側の L. 1. ant. 及び L. l. inf. 刺戟

1）両視床間及び一側結合腕切離後, 結合 㬿切離側の L. l. ant. を刺戟した場合は，全 6 例中 5 例飞全身同封の瘵攀を認め，1例飞結 合㬵切離反刘側の前後肢飞同時飞始発し，結 合䛷切離側の前肢，次いで後肢に波及する march を認めた。

訤表25（全身同時の場合）

\begin{tabular}{|c|c|c|c|c|c|}
\hline \multicolumn{3}{|c|}{ 実験番费 531} & \multicolumn{2}{|c|}{ 体重 $13.8 \mathrm{~kg}$} & \multirow{2}{*}{$\frac{\text { ㅇ }}{\text { 過 }}$} \\
\hline 経 過 & 特 間 & 痤 & 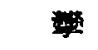 & 経 & \\
\hline $\begin{array}{l}\text { 分 } \\
0\end{array}$ & $\begin{array}{l}\text { 秒 } \\
0\end{array}$ & \multirow{2}{*}{\multicolumn{4}{|c|}{ 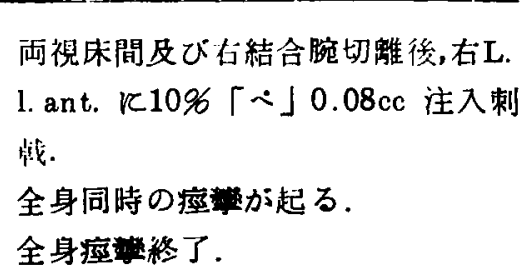 }} \\
\hline 1 & $\begin{array}{r}19 \\
5\end{array}$ & & & & \\
\hline
\end{tabular}


（偏側 march.の場合）

\begin{tabular}{|c|c|c|c|c|c|}
\hline \multicolumn{3}{|c|}{ 实験番号 534} & \multicolumn{2}{|c|}{ 体重 $11.8 \mathrm{~kg}$} & \multirow[b]{2}{*}{ 過 } \\
\hline 経 過 & 特 間 & 痓 & 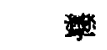 & 経 & \\
\hline $\begin{array}{l}\text { 分 } \\
0\end{array}$ & $\begin{array}{l}20 \\
21.5 \\
32\end{array}$ & \multicolumn{4}{|c|}{ 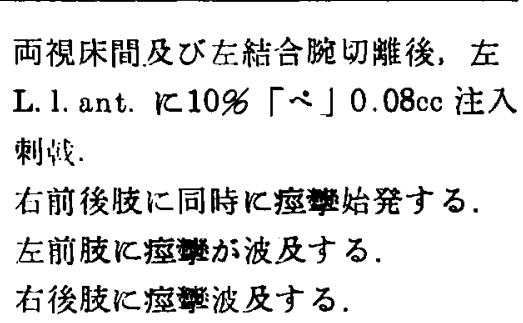 } \\
\hline 1 & 48 & \multicolumn{4}{|c|}{ 全身痤整まつたく終了 } \\
\hline
\end{tabular}
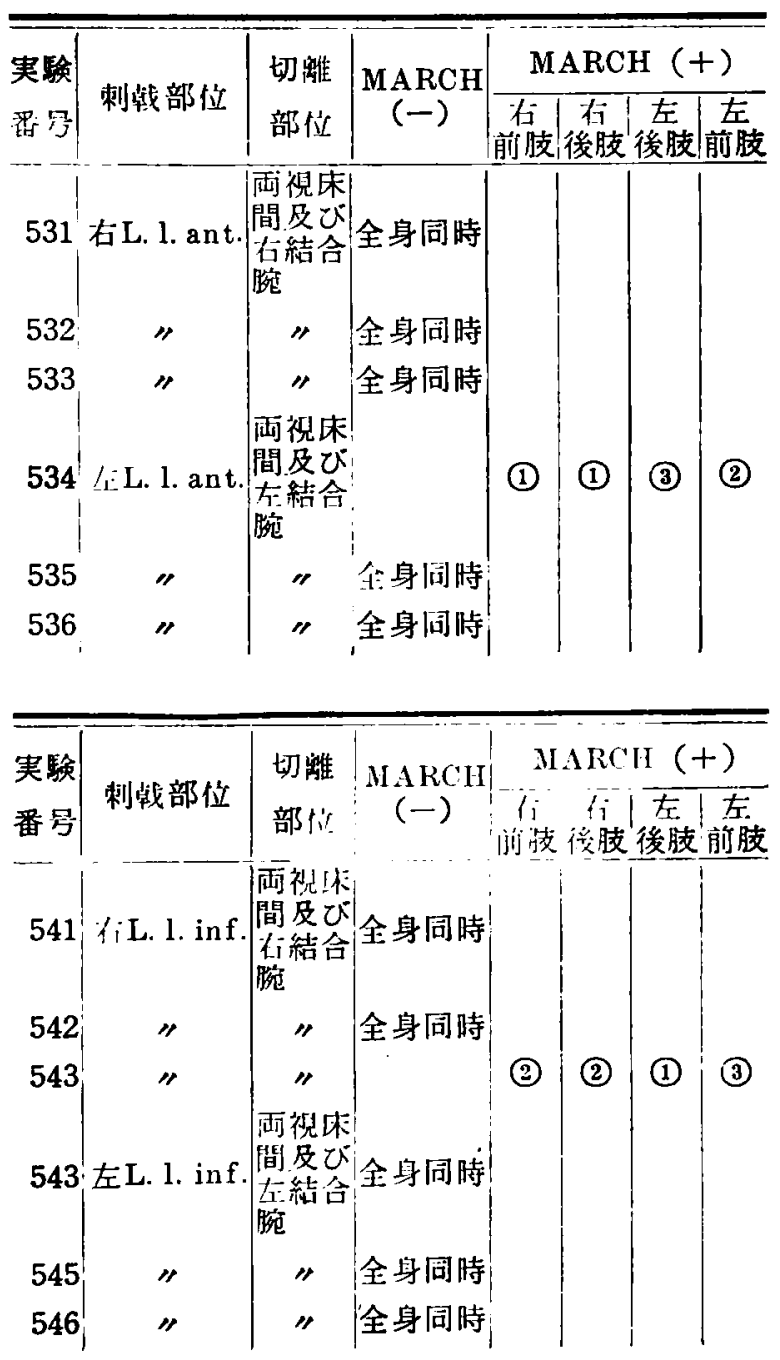

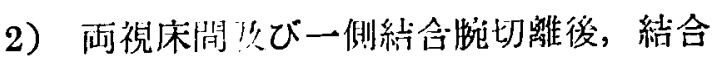
胎切碓側の L. l. inf. を制戟した埸合心，企6

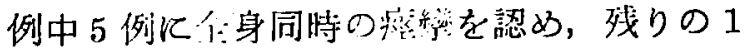
例は結合腕切離反対側の後肢に始管し, 次い で結合腕切攡側の前後肢同川に波只し，さら 飞結合腕切離反対側前肢に波以寸る march を示した。
第7 項 小 括

1）脳梁切離後，一側の L. l. ant. 及び L. 1. inf.を制戟すると，いずれの場合も全身同時

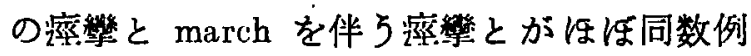
に認められる。 march を伴う瘐彎の場合, L. l. ant. 刺戟では主として刺戟側の前肢飞始 発する完全.marchを，L. l. inf. 刺戟では主と して刺载側の後肢に始発する完全 march を 示す.

2）两視床間切㒕後, 一側 L. 1. ant. 及び L. 1. inf. を刺戟すると，いずれも大多数例に march を認め, L. l. ant. 剌戟では主として刺 皒側前肢飞始発する完全 march を， L. 1. inf. 剌戟では剌戟側の前肢または後肢に始発する 完全 march を示す。

3）一側結合腕切離後, 反対側の L. l. ant. 及び L. 1. inf. を刺戟すると，いずれる全例に march を伴う应攣を認める. L. l. ant. 刺戟の 場合は主として切離反対側の前肢に始発する 完全 march を， L. l. inf. 刺戟では主として 切離反刘側の後肢，とき飞前肢に始発一る完 全 march を示す。

4）一側結合腕切帤後後, 同側の L. 1. ant. 队び L. l. inf. を剌戙すると，いずれる全例に march を伴 5察攣を認める. L. l. ant. 刺戟の 埸合は主として切離反刘側の後肢，とき飞前 肢に始発する完全 march を示し， L. l. inf. 刺 戟では主として切離反刘側の後肢に始発する 尤住 march を示す。

5）両視床間灭び一側結合䛷切離後, 絬合 䛷切離反対側の L. l. ant. 及び L. 1. inf. を 刺戟すると，いずれる全例飞絬合椸切離反対 側飞始発し，切離側飞 march を欠如する偏 側 march を示す。そうして L. l. ant. 刺戟で は前肢飞始発し， L. l. inf. 刺戟では後肢に始 笔する。

6）両視床間及び一側結合腕切離後, 結合 脆切離側の L. l. ant. 及び L. l. inf. を刺戟す ると，いずれるほとんど全例に全身同時の痤 攣を示す。 
第 6 節 一側站に両側皮質運動領剔除後， 小脳皮質刺戟による痤變の体飾波

. 及Кついて

第 1 項一側皮質運動領剔除傜，同側

L. 1. ant. 剌韩

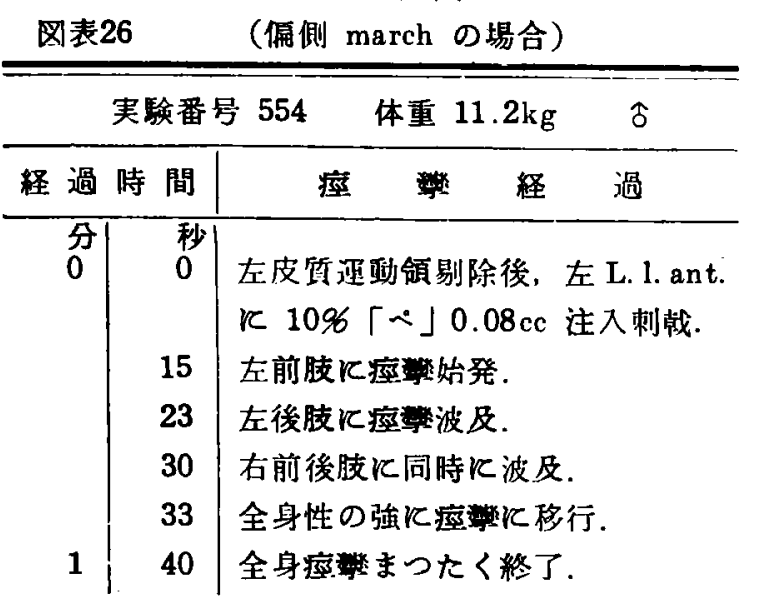

\begin{tabular}{|c|c|c|c|c|c|c|c|}
\hline \multirow{2}{*}{$\begin{array}{l}\text { 実験 } \\
\text { 番号 }\end{array}$} & \multirow{2}{*}{ 刺戙部位 } & \multirow{2}{*}{$\begin{array}{l}\text { 剔除 } \\
\text { 部位 }\end{array}$} & \multirow{2}{*}{$\begin{array}{c}\text { MARCH } \\
(-)\end{array}$} & \multicolumn{4}{|c|}{ MARCH $(+)$} \\
\hline & & & & 年前肢 & & 左 & - \\
\hline 551 & 右L. 1. ant & $\begin{array}{l}\text { 石速 } \\
\text { 怔領 }\end{array}$ & & (1) & (2) & (3) & \\
\hline 552 & " & " & & (1) & (2) & (3) & \\
\hline 553 & $"$ & " & & (1) & (2) & (3) & \\
\hline 554 & 左L. l. ant & 左運 & & (3) & (3) & (2) & \\
\hline 555 & $"$ & " & & (3) & (3) & (2) & (1 \\
\hline 556 & $"$ & " & & (2) & (2) & (2) & ( \\
\hline 557 & " & " & & (3) & (2) & (1) & \\
\hline 558 & " & " & & (3) & (3) & (2) & \\
\hline
\end{tabular}

この場合は, 令 8 例中 7 例飞剔除側の前肢 飞始発し，その側に march を有し，剔除反 対側飞 march を欠如する偏側 march を示し た. 残り 1 例は剔除側後肢飞始哞し, 剔除反 対側後肢に波及し，次いで両側前肢に同㑏に 波及する march を示した。

第 2 項 一側皮質運動領剔除後，同側 L. l. inf. 刺戟

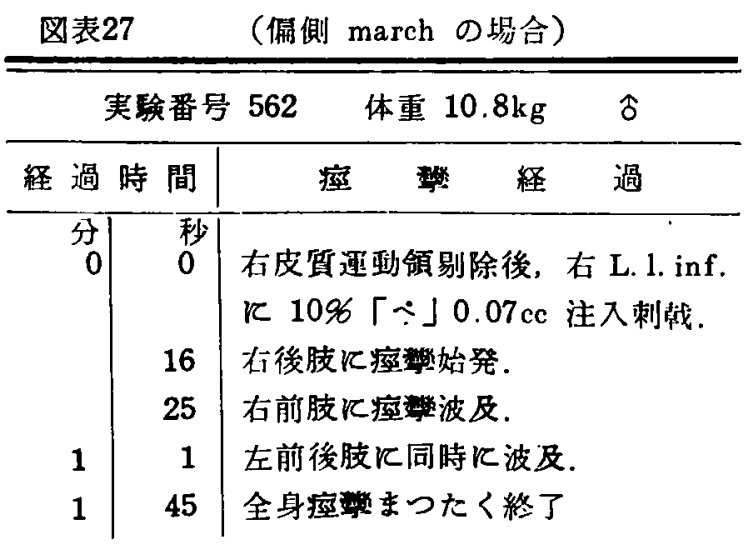

\begin{tabular}{|c|c|c|c|c|c|c|c|}
\hline \multirow{2}{*}{$\begin{array}{l}\text { 実䮖 } \\
\text { 番号 }\end{array}$} & \multirow[b]{2}{*}{ 刺战部位 } & \multirow{2}{*}{$\begin{array}{l}\text { 剔除 } \\
\text { 部似. }\end{array}$} & \multirow{2}{*}{$\underset{(-)}{\text { MARCH }}$} & \multicolumn{4}{|c|}{ MARCH (t) } \\
\hline & & & & & & & 砉肢 \\
\hline 561 & 仿L. I. inf. & 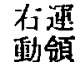 & & (1) & (1) & (2) & (2) \\
\hline 562 & " & $"$ & & (2) & (1) & (3) & (3) \\
\hline 563 & $"$ & & & (2) & (1) & (3) & (3) \\
\hline 564 & taL. 1. inf. & 左速 & & (2) & (2) & (1) & (1) \\
\hline 565 & $"$ & " & & (2) & (2) & (2) & (1) \\
\hline 566 & $"$ & $"$ & & (3) & (3) & (1) & (2) \\
\hline
\end{tabular}

この場合は，全 6 例中 3 例飞剔除側後肢に 始発し，剔除反対側には march を欠如する 偏側 march を示し，2例は剔除側の前後肢 同時任始発し，次いで剔除反対側の前後肢に 同時飞波队する march を示した。 残り 1 例 は剔除側前肢飞始発し, 次いで剔除側㣪肢,

剔除反対側前後肢飞同時飞波及する march を 示した.

第3 項一側皮質運動領剔除後, 反対側

\begin{tabular}{|c|c|c|c|c|c|}
\hline 困表28 & & $\begin{array}{r}\text { L. l. ant. } \\
\text { （全身 }\end{array}$ & 制戟 & & \\
\hline 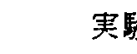 & 负番号 & 571 & 体重 1 & $6 \mathrm{~kg}$ & $\hat{\delta}$ \\
\hline 経 過 時 & 間 & 痤 & 慗 & 経 & 過 \\
\hline $\begin{array}{l}\text { 分 } \\
0\end{array}$ & $\begin{array}{c}\text { 秘 } \\
0 \\
27\end{array}$ & 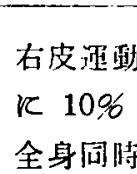 & 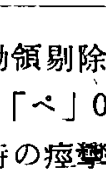 & $\begin{array}{l}\text { t } \\
8 \mathrm{cc} \\
\text {, 起 }\end{array}$ & $\begin{array}{l}\text { l. ant. } \\
\text { 入刺战. }\end{array}$ \\
\hline 1 & 35 & 全身性痘 & 祭まつ & 〈終 & \\
\hline
\end{tabular}

\begin{tabular}{|c|c|c|c|c|c|c|c|}
\hline \multirow{2}{*}{$\begin{array}{l}\text { 実䭻 } \\
\text { 舀号 }\end{array}$} & \multirow{2}{*}{ 刺战部任。 } & \multirow{2}{*}{$\begin{array}{l}\text { 剔除 } \\
\text { 部位 }\end{array}$} & \multirow{2}{*}{$\underset{(-)}{\operatorname{MARCH}}$} & \multicolumn{4}{|c|}{ MARCH $(+)$} \\
\hline & & & & & $\begin{array}{l}\text { 石 } \\
\text { 㣪肢 }\end{array}$ & 後肢 & $\frac{E}{\text { 前肢 }}$ \\
\hline 571 & 左L. 1. ant. & 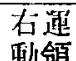 & 全身同時 & & & & \\
\hline 572 & " & " & 企身同時 & & & & \\
\hline 573 & 标L. 1. ant. & 左速 & 企身同時 & & & & \\
\hline 574 & $"$ & $"$ & 全身同時 & & & & \\
\hline 575 & $"$ & $"$ & & (1) & (1) & (2) & (3) \\
\hline 576 & $"$ & "r & 全身同時 & & & & \\
\hline
\end{tabular}

この場合は，全 6 例中 5 例飞全身同時の痤 彎を認め，残り 1 栣は剔除反対側の前後肢同 洔飞始発し，剔除側後肢，さらに剔除側前肢 飞波及する march を示した。

第 4 項一側度質凎動領剔除後, 反対側 L. 1. inf. 刺战 


\begin{tabular}{|c|c|c|c|c|c|}
\hline \multicolumn{3}{|c|}{ 実験番号 587} & \multicolumn{2}{|c|}{ 本重 $13.5 \mathrm{~kg}$} & \multirow{2}{*}{$\frac{\text { 우 }}{\text { 過 }}$} \\
\hline 経 過 時 & 間 & 疮 & 兴 & 経 & \\
\hline $\begin{array}{l}\text { 分 } \\
0\end{array}$ & $\begin{array}{l}\text { 秒 } \\
0\end{array}$ & \multicolumn{4}{|c|}{ 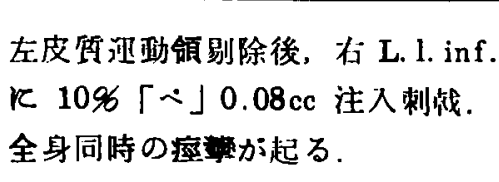 } \\
\hline 2 & 5 & 全身痤 & まつた & 䊏了 & \\
\hline
\end{tabular}

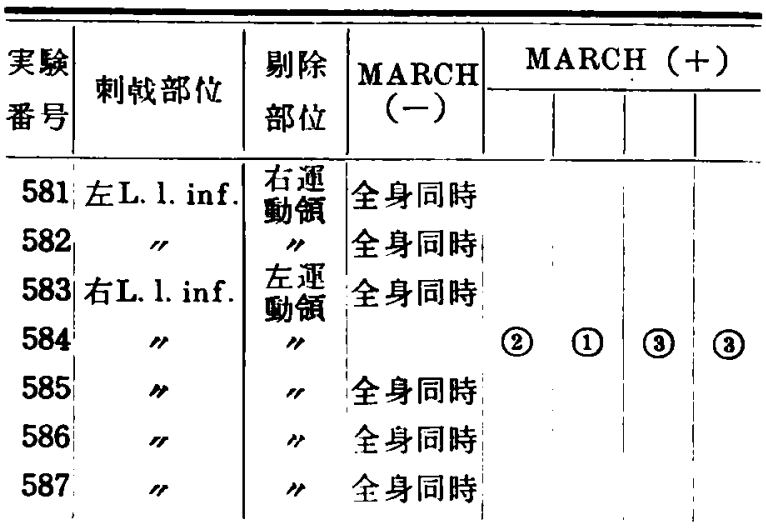

この場合は，全 7 例中 6 例飞全身同時の痛 摮を認め, 残り 1 例に剔除反対側の後肢に始 発し，その側に march を有し，剔除側には march を欠如する偏側 march を認めた。

第 5 項 両側皮質運動領剔除後，一側 L. 1. ant. 次び L. 1. inf. 刺戟 図表 30

\begin{tabular}{|c|c|c|c|c|c|}
\hline \multicolumn{3}{|c|}{ 実殹番号 591} & \multicolumn{2}{|c|}{ 体重 $12.3 \mathrm{~kg}$} & \multirow{2}{*}{$\frac{\hat{o}}{\text { 過 }}$} \\
\hline 経 過 & 持 間 & 疗 & 然 & 経 & \\
\hline 分 & $\begin{array}{l}\text { 秒 } \\
0\end{array}$ & \multirow{2}{*}{\multicolumn{4}{|c|}{ 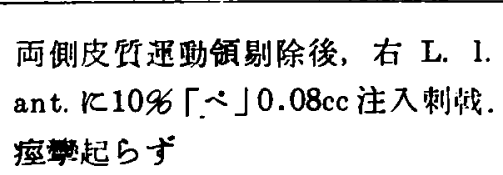 }} \\
\hline 2 & 0 & & & & \\
\hline 2 & 20 & \multirow{2}{*}{\multicolumn{4}{|c|}{ 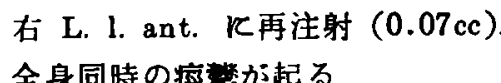 }} \\
\hline 3 & 28 & & & & \\
\hline 4 & 30 & \multicolumn{4}{|c|}{ 全身痙唒終了 } \\
\hline
\end{tabular}

\begin{tabular}{|c|c|c|c|c|c|c|}
\hline 刺战部位 & 剔除部位 & 例数 & & 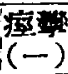 & $\begin{array}{c}\mathrm{MARCH} \\
(+)\end{array}$ & $\begin{array}{c}\text { MARCH } \\
(-)\end{array}$ \\
\hline L. l. ant. & 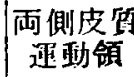 & 11 & 11 & 0 & 0 & 11 \\
\hline L. l. inf. & $"$ & 6 & 6 & 0 & 0 & 6 \\
\hline
\end{tabular}

图表30のよ5飞，両側皮質運動領を剔除す ると，L. l. ant. 刺戟の全11例， L. l. inf. 刺戟 の全 6 例のいづれすすべての例飞全身同時の. 痤彎を認めた。

\section{第 6 項 小 括}

1）一側皮質通動領剔除後，同側 L. I. ant. を刺戟すると，剔除側前肢飞始発し；剔除反 対側飞は march を欠如する偏側 march を示 す.

2）一側皮質運動領剔除後, 同側 L. l. inf. を刺戟すると剔除側の後肢または前肢飞始発 し，剔除反対側には march を欠如する偏側 march を示す。

3）一側皮質運動領剔除後，反对側 L. 1 . an1. 及び L. l. inf. を刺戟すると，いずれの 場合むほとんど全例飞全身同時の瘵揱を示す。

4）両側皮質運動領剔除後，一側 L. l. ant. 队び L. l. inf. を刺戟すると，いゔれの場合る 全例飞全身同時の痤攣が認められる.

\section{第 4 章 総括竝に考按}

小脳皮質にペンタゾール剌戟を行つた場合， 小脳半球である L. l. ant. et inf. 欠び L. semilunarisの刺戟では瘵攣を認め，小脳虫部 であるCulmen, Declive, Pyramis, Uvula 等の 刺哉では全く痤變を認めなかつた。渡辺 ${ }^{(2)}$ 小脳皮質にNicolinizationを行つて同㥞の結果 をえている．このようと小脳半球の刺戟で座 卛を生じ，小脳虫部の刺戟では篧彎が起らな いのはおそらく両者の間の解剖学的及び機能 上の差異によるものと考えられる。すなわち Edinger ${ }^{19)}$ 以来多数の学者によつて，小船は 系統発生学的に新しい部分である新小脳と古 い部分である旧小脸とに区分され，両者の間 には機能上飞も差のあることが一般認めら れている.この系統発生学的な区分によると 大体飞抢いて小脳半球は新小脳飞，小脳虫部 は旧小脳そ属している。 また Larsell20) 及び Dow ${ }^{21)}$ の解剖学的研究飞よると，宗族発生的 飞古い旧小脳のうち, Lingula, L. centralis, Culmen, Pyramis, Uvula, Nodulus 及び新小脳 の Declive からの線維は N. fastigius を通つ て延䯑道にいたるが，新小脸及び旧小脸の片葉 旁小葉 (L. semilunaris sup. et inf.) からの線 維は N. dentatus を通つて中脳にいたるとい

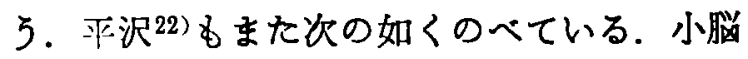


そは中枢性及び末梢性の連絡があるが中枢性

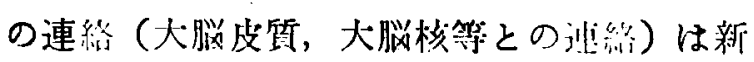
小兴皮質 (小脳半球) を通り，末梢性の連絡 (末梢体部，瓷髄等との連絡）は旧小脳（皮 質虫部）を通ると。

小脳核 (N. dentalus, $\mathrm{N}$. interpositus, $\mathrm{N}$. fastigius）の刺戟の場合もほとんど暃例に㾞 杽を認めなかつた。 たた $\mathrm{N}$. dentatus 刺戟で 20例中 2例飞瘵熋を認め，1例は今身同時の 㽷摮で, 残り 1 例は刺戟側の前後肢同時に始 発し, 次いで反対側の前肢, 後肢の順飞波及す る偏側 march を示した. 渡辺 ${ }^{22}$ の実験では全

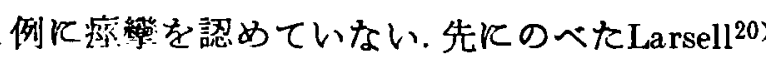
队び Dow ${ }^{21)}$ の研究によつて知るごとく， 小脳半球よりの伝導路が $\mathrm{N}$. dentatus を通つ ていることを考えると，N. denlatus 刺戟では 当然噔蒘が起ることが想像される。しかし赛 際には私及び渡辺12の実験からわかるよ5に N. dentatus 刺戟では瘠繁が起り難い。この理 由は明かでないが，たた N. dentatus の化学 的刺戟に対する刺戟闌值が高いものと想像さ れる. Sachs 及び Fincher ${ }^{23)}$, Magoun ${ }^{24)}$, Hare

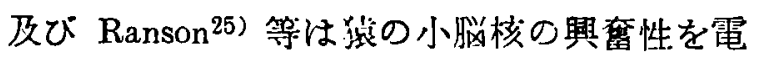
気で調べているが，これによると N. dentatus の刺戟閶值は高いが，しかしこ〉を強く刺戟 すると同側の前肢と後肢に屈曲と件展の速か な交互運動が現われるとのべている。

小畄半球皮質 (L. l. ant. et inf., L. semilunaris）の剌戟では合計 68 例の全例に㱂卛を 認め，このうち体䬣波及が認められるものが 35 例，全身同時のすのが 33 例で，それぞれ ほぼ同数例認められる. 教室の吉田 ${ }^{(4)}$ ，制 路15ik上る大畄皮質運動領, 皮質下核の単独 刺戟では全例飞 march が認められている. これに比へて小脳刺戟の場合は約半数例飞全 身同時の应彎が認められ，大脳皮質及び皮質 下核刺戟の場合に比して march の型にもか なりの例外が認められる。しかし一側結合腕 を切離すると，小脳半球の単独刺戟の場合飞 約半数例に認められた全身同時の痤熋はなく なり全例飞 march を伴つた痤攣が認められ る。また一側結合腕切離の場合はいずれの側
の半球皮質刺戟でも，必ず断清倠反刘側の前肢 または後肢飞始発する主として完全 march で，結合腕を切離しない場合に比して非常に 明膫な march が認められる。このことは興 味深い事笑であつて，以上のことから小船河 半球間には線維結合が存在することが䓅えら れる.すなわち一側の小脸半球を刺韩した場 合に興舊は同側の結合腕のみならず容易に他 側の半球に伝わり，その側の結合腕を通つて 小脳を去ると考えられる。そうして結合腕を 切離した場合は切離しない場合飞比して march が明瞭に現われることから考えて，小 脳より出る伝導路には，一つは制戟側小脸皮 質より同側の結合腕を通り反対側の視床にゆ くものと，も5一つは反対側小脳に伝わり反 対側結合腕を通り同側視床にゆくあのとの 2 つの伝導路があり, これが互に重なりあつて march が混乱し，欠如していたすのが，一側 結合腕の切離により視床にゆく興畕伝導路が 一つになるため, 一側結合腕切離の場合には 全例飞 march を伴5よ5になりそてて march が明膫になつてくるものと思われるの である。

小脳皮質の単独刺戟で体節波及の認められ る場合, L. l. ant. の刺戟では march を認め た14例中12例飞刺戟側の前肢飞僢攣が始発し， L. l. inf. の刺戟では13例中 8 例に刺戟側の後 肢， 3 例飞刺戟側の前肢飞始発する痤攣を認 めた. L. semilunaris 刺戟は sup. と inf. を 一緒にその後部で行つたが，この場合は 8 例

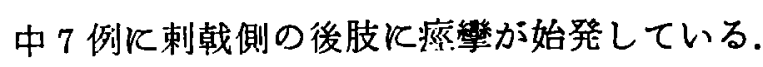
いま剌戟部位と丞攣の始発部位の関係を小脳 機能の局在という点から考察して見よ5.

小脸皮質の機能局在とい5問題に先鞭をつ けたのは Bolk17) であつて, 多数の哺乳動物 の小脳を比較して小脳皮質の基本形を劣兄， 次にのベるような場所による栕動の中枢を仮 定した。すすなわち, 虫部は体の左右両半が共 同して行う運動を半球は左右が別々飞行 運動をつかさどり, Lobus anterior は頭部, Lobus simplex は頸部及び項部, Lobus paramedianus は嵒幹, Lobus ansiformis (Crus 1 ) 
は前肢, Lobus ansiformis (Crus II)は後肢 の運動中枢であろうという。この Bolkの 説はその後多くの学者 (van Rijnberk ${ }^{26)}$, Rothmann ${ }^{27}$, André Thomas 队び Durupt ${ }^{28}$,

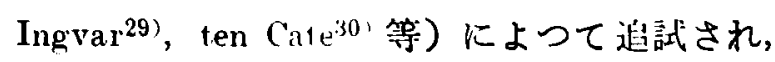
大体に正しいとされている。しかし細部に括 いては諸家の意見は必ずしも一致していな い. André-Thomas 及び Durupt ${ }^{28}$ は後肢の中 枢としては Crus II と L. paramedianus 及び L. parafloccularis の合するあたりであるとい 5. ten Cate ${ }^{30)}$ は L. parafloccularis の前半分 を前肢，後半分を後肢の中枢としている.

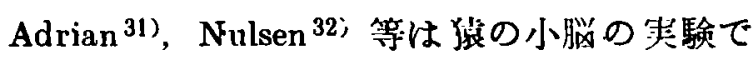
L. anterior の前端飞尾部，その後に後肢，そ の後に前肢ささらにその後方に顔面の中枢を 認めている. Snider 及び Stowell ${ }^{33)}$ は猺や 猫の実験で L. anterior の後方から L. simplex そかけて中块部に顔面, その外側飞前肢,さ らと前方飞後肢の中枢を認めている。最近 Hampson $^{34)}$ は L. paramedianus では後肢の中 枢が前肢のそれより後方にあるといつてい る.また Bolk ${ }^{17)}$ の説に反対する学者として Luciani ${ }^{6}$ (は小脳は全体として㗢き，機能を解 剖学的に区分することができるとすればそれ は左右に分れるということだけで，小脳の 各半球は同側の骨格筋を支配するという。

Sherrington ${ }^{7122}$ もこの Luciani の説を支持し ている。また Holmes ${ }^{35)}$ は第一次大戦に扔け る戦賃の結果から Bolk17) のい5よ5な小脳 の細かい機能の局在に反対している.

これを要するに現存小脳機能の局在, すな わち運㡖機能の中枢飞関する諸家の意見は必 ずしも一致して打らず完全な解答は与えられ ていない。しかし現在多くの学者が認めてい るように小脸機能の局在があるとすれば，大 脸の場合と同様にその刺戟部位たる運型中枢

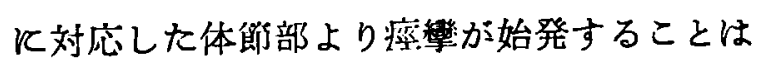
容易に理解できる、私の䒠験結果より逆に小 脳機能の局在を考えると，L. l. ant. (Crus I) は前肢, L. l. inf. (Crus II) は大休後肢の中 枢ということになり Bolk17) の説に一致する。 L. semilunaris（後部）す後肢の中枢という.こ
とができるが，これは Bolk'17) の説にあては まらずむしろ ten $\mathrm{Cate}^{30)}$ の説と一致してい る.

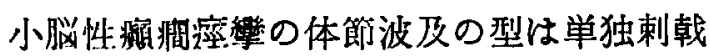
の場合では図表 1，2，3，の如くで，全 35例 中28例に後肢を介して他側飞波及する $\mathrm{march}$ を認め，5例飞前肢を介乙て他側飞波及す る march を認めた. Clark, Ward, Payen, Cawden ${ }^{9}$ 等は猫の大脳及び小脳皮質の電気刺 戟により痙㝈を認め, その際の march を C 型， $\mathrm{S}$ 型及び $\mathrm{U}$ 型の 3 つと分け，小脳制韩の 場合は $\mathrm{S}$ 型，すなわち剌战側前肢一刺戟反対 側前肢一刺戟側後肢一剌戟反対側後肢の順に 波及する march が最も多く認められる，とのべ ている、しかし彼等のいろ小脳刺戟の場合の 瘵繁は "slow seizure”といいあたかる "slow motion picture” の如き強縮性の緩漫な運動で， 私の垁験に括けるがごとく化学的刺戟で起し た間代性凐繁とは性質の異なるすのと考えら れる。

脳梁切離後, 一側小脳半球を刺戟した場合 は marchを示するのと，欠如するすのとが ほぼ同慗で，単独刺戟の場合と比へでとん ど変化がみられなかつたが，両視床間を切離 し一側小脳半球を刺戟すると大多数例に刺戟 側の前肢または後肢に始発する完全 march を示した。また両側視床間及び一側結合腕を 切離して結合腕切離反対側の小脳半球を刺戟 すると結合腕切離反対側の前肢または後肢に 始発し，結合腕切離側には march を欠如す る偏側 march が認められた。 この成績は極 めてよく一致して招り，このことから小脳刺 戟の場合の䵇攣の march は両小脳半球間括 よび両視床間を通つて他側飞波及すると考克 られる。すなわち一側結合腕及び両視床間切 離を行い結合䏽切離反対側を刺戟すれば， $\operatorname{march}$ の波及は刺戟同側の結合腕のみを通り， 反対側視床のみにいたり他側の視床には興窑 が伝わらないために常に刺戟側飞始発する偏 側 march となるすのと䒴えられる. しかし この場合結合腕切離側の刺戟ではほとんどす べてに全身同時の痙彎を認め march を示さ 
なくなるが，この理由については不明である。 この結果は後述するごとく，一側視床剔除の 場合とまつたく同様で，両視床間切離に一側 結合腕切離を加えたことは一側視床剔除と同 一の意義があるものと思われる。

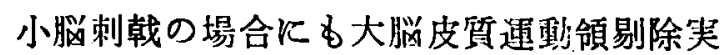
験から明かなよ5飞小脳皮質と大脸皮質の間 飞密接な関係が存することが理解できる。す なわち一側皮質運動領剔除後, 剔除側の小脳 半球を刺戟すると，明か飞剔除反対側には march を欠如し，剔除側飞は march を有す る偏側 march を認めた。剔除反対側の刺戟 では大多数例に全身同時の应卛を認め march を示さなかつた，両側皮質運瑨を領剔除する と全例全身同時の瘵攀を認め march はま つたく認められない。このことより小脳剌戟 の場合も体節波及を伴つた病学等が起るために は皮質運動領の存在が必要であるということ ができる。

小脳と大脸皮質との関係について, Rossi36) は新小脳を刺戟すると大脳皮質運動領の興篦 性が高まることを明かにし，Walker ${ }^{37)}$ は新 小脳を刺戟すると分野 4 の自発的活動電流の リスムが変化することをみている，そして旧 小脳を刺戟したのではこのよ5な效果はみら れないといつている。また Adrian"11) は猺の 大脳皮質運動領を刺戟すると小脳の前葉に非 常によく限留した反心が現わ机ることをみて いる. Magoun ${ }^{34)}$ は小脸皮質の Crus I 及び Crus II と大脳前頭渠と密接な関係があるとい 3. また増田 ${ }^{33)}$ の研究飞よると大脳前頭葉よ り橋核の前部を介して，新小脳の後部ことに Lobus biventer, Tonsilla す广わち Bolk ${ }^{17)} の$ Crus I， L. paramedianusの部分と密接な関係 があるという。これらのことと小脳皮質の Crus I は前肢, Crus II は後肢の中枢であると いう Bolk ${ }^{17)}$ の説とを考えあわすと興咏㳭い すのがある.

しからば小脳皮質と大脳皮質とを結ぶ伝導 路はどうであろろか。この問題は今日まだ完 经化解決されていないが，平沢22)飞よれば 小脳皮質と大脳皮質の間の連絡は小脳皮質か
ら大脳皮質飞いたる上行路と大脳皮質から小 脳皮質にいたる下行路とよりなり，一般的に は閉したーつの伝導賥をなしている.上行路

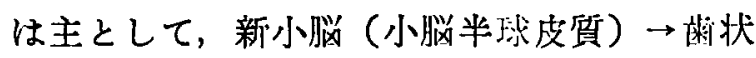

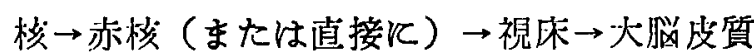
にいたる伝導路である。この上行路にくらべ 下行路は複雑であり，多くの伝導路を有して いて，次の如きものがあるという。

1）皮質橋路を経て小脸皮啠にいたるもの 大脸皮質一(皮質橋路) $\rightarrow$ 橋㤥一(橋小脳 路) $\rightarrow$ 新小脳皮質

II）中脳被蓋を経て小脸皮睤にいたるもの

1）大脳皮質 $\rightarrow$ 赤核 $\rightarrow$ 小脳皮質

2）大脳皮質 $\rightarrow$ 視床 $\rightarrow$ 赤核 $\rightarrow$ 小脳皮質

3）大脸皮質 $\rightarrow$ 視床 $\rightarrow$ 大脳慔（線状体，淡 荅球) $\rightarrow$ 赤核 $\rightarrow$ 小脸皮質

4）大脳皮質 $\rightarrow$ 大脸核 $\rightarrow$ 赤核 $\rightarrow$ 小脳皮質

5）大鼡皮質 $\rightarrow$ 大脳核 $\rightarrow$ 視床 $\rightarrow$ 赤核 $\rightarrow$ 小脳 皮質

III）錐体路を経て小脳皮質にいたるもの 大脳皮質一(錐体路) $\rightarrow$ 橋㤥 $\rightarrow$ 小脳皮質 富永 ${ }^{39}$ 及び教室の吉田 ${ }^{(4)}$, 牢路 ${ }^{(5)}$ は皮質下 核の刺戟の場合飞生じた興䅦は一心火兴皮質 にもどり，そこの皮質運㡖中枢の配列飞従つ て march が波及するとのべているが，小脸 制戟の場合に主興第は一応大脸皮質に及ぶこ とが私の大脳皮質剔除笑験の結果より考元ら れる.この場合の興態の伝導は先にのべた上 行路によるるのと考えられる。すなわち殞澗

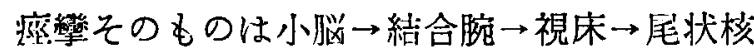
ーレスズ恔 $\rightarrow$ 黑㤥にいたる錐体外路を通つて 伝わるとしても， march の発動は視床をへて

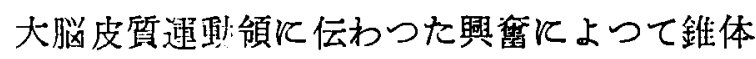
路を通つて指向されるものと思われる。

一側視床を剔除するといづれの側の小脳半 球を制戟しても，体即波及の認められるすべ ての例飞剔除反対側飞 march を欠如する偏 側 march が認められ，両側視床を剔除する と全例飞瘵彎が起らなかつた。またレンズ核 剔除笑䮖の結果る視林剔除の場合とほとんど 同様で，体榔波及の認められるほとんど全例 飞剔除反刘側飞 march を欠如する偏側 march 
を認め，両側レンズ核を剔除するとほとんど 全例に瘁摮を認めなかつた。一側視床剔除に よつて剔除反対側に march が欠如する偏側 march を示すのは，視床剔除によつて剔除側 の皮質運動領への興窗の到達が遍断されるた めと考元られるけれどる，一側レンス核剔除 の場合に同様の結果が起ることに対しては説 明がつかない。これにはるつと複雑な理由が あるのであろ3．次に両側視床またはレンズ 核を剔除後，小脳刺戟により痤紸が起らない 理由としては痤卛そのるのの伝導路の遗断に よるものと思われる。をたこの実験より皮質 運㡖領と同様，視床，レンズ核の一側剔除は その反对側に march を欠如せしめることが わかる。

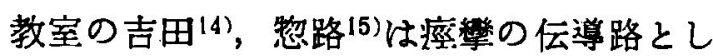
$\tau$, 大脳皮質 $\rightarrow$ 視床 $\rightarrow$ 尾状核 $\rightarrow$ レンズ核 $\rightarrow$ 黒 核の錐体外路をあげ，体節波及を発動する大 脳皮質への連絡として視床及びレンズ核より 大脳皮質の顔面，前肢，後肢各領野飞それぞ れ reverberating circuits (Fulton ${ }^{40)}$ ) が存在 していることを認めている.

今こつに一つの問題があるのは，一側の皮 質運動領, 視床, レンズ核及び尾状核剔除後, 剔除反対側の刺戟ではいら゙れる大多数例に全 身同時の㙥攣が認められることで，この理由 そついては明確な解答をみいだしえない。

以上，私の実験に対する考按を総括し，こ れを schema で示すと第 3 図の如くなる.

すなわち一側小脳半球皮質の刺戟により生 じた興篦は同側結合腕を通り反対側視床にい たる. また一方両半球間の交連線維により反 対側小脳にもいたり，その側の結合椸を経て 刺载同側の視床にもいたる。視床以下の伝尊

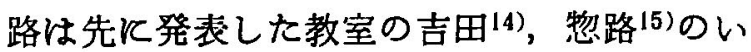

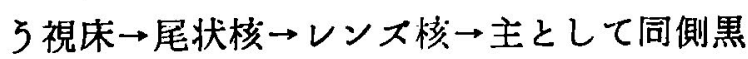
核，一部は反対側黒核にいたる伝導路につな がつているるのと考えられる。

この schema スは多少の推測は加わつてい るけれどす大体に正しいるのと考兄てょいと

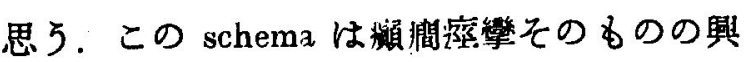
盒の伝導路を示するのであつて, 痤笔の伝導
第 3 図

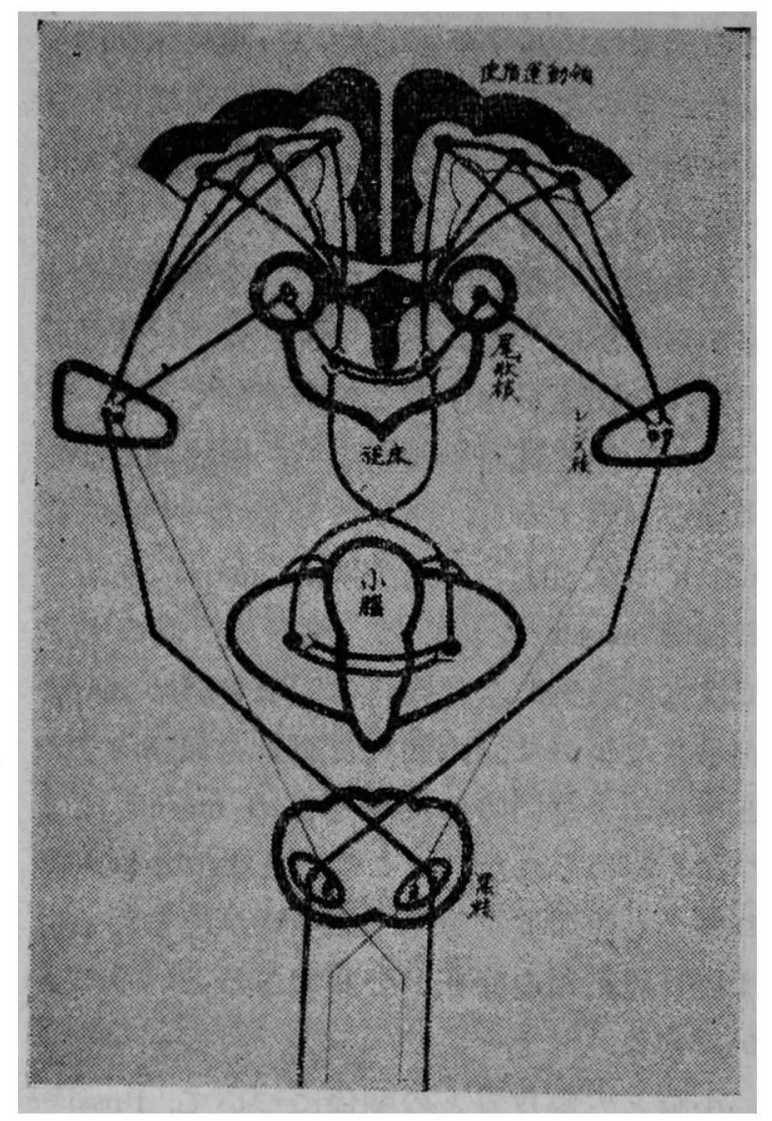

路はかくの如き錐体外路系によるるのと思わ れるが，体節波队を指问するものは皮澌運動 領の各領野から下降する錐体路系炕よるもの と想像されるのである.

\section{第 5 章 結論}

1）小脳半球皮質のペンタゾール刺戟によ

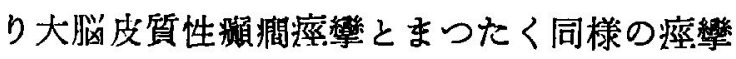
を認め，この場合体節波及を伴うものと全身 同時のものがほぼ同数例敒認められる.

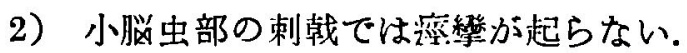
小脳核の刺戟でも起りにくい.

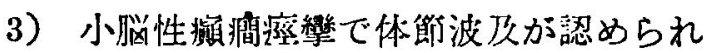
る場合, 痤攣の始発部位は, L. l. ant. 刺戟で は刺戟側前肢，L. l. inf. 队び L. semilunaris 刺戟では主として刺戟側後肢である。

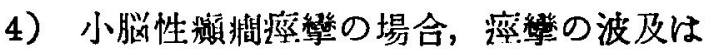
雨小脳半球間及び両視床間を通つて一側より 他側に波及与る。

5）小脳性澒澗㽷卛の場合も体節波及を伴 つた凐卛が起るためには大脳皮質運動領の存 在が必要である. 
6）画側皮質㞄甽領の剔除では march は 久如するが全身同版の痙攀は起る。

7）汁側䘽床または闬側レンズ核を剔除す ると小脂半球剌戟による病攀はまつたく起ら ない。

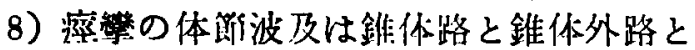
の密接な協同作用により起つてくる。すなわ

\section{文}

1) Jackson: Selected Wrighting of John Hughling Jackson, London, I ; 410, 1931.

2) Fritsch u. Hitzig Arch. Anat, u. Physiol., $37 ; 370,1870$.

3) Thomas Willis Cerebri Anatome, 1644.

4) Rolando Stamperia Privilegiata. 14 ; 98 , 1809.

5) Ferrier: The Functions of the Brain, London. $15 ; 323,1876$.

6) Luciani Il cervelleto. Nuovi studi di fisiologia normale e patologia, Florence, Monnier $9,320,1891$.

7) Sherrington 1) J. Physiol., 22 ; 319332, 1898. 口) Schäfer Text-book of Physiology, 2, 697-782, 1900 .

8) Clark : J. f. Neurophysiol., 2 ; $19-35,1939$.

9) Clark, Ward, Parell and Cowden Arch. Neurol. Psichial.. ('hirago, 49; 244-253, 1943.

10) 林. 条件反射， $7 ； 64-72 、 1943$.

11）石塚：条件反射， 4；70-82. 1942.

12）渡辺：条件反射，9；49-72，1943.

13）尾崎：条吽反射，5；79-88，1942.

14）吉田：岡山医学会雑誌，64；1536-1551, 1952.

15）惣路：岡山医学会雑誌，65；1311-1345, 1953.

16) Ellenberger u. Baum : Anatomie des Hundes, 447, 1891.

17) Bolk - Das Cerebellum der Säugetiere. Harlem, Bohn, 1906.

18）森，沼本，医没生物，18；98，1951

19) Edinger Anat. An\%, 35, 319, 1909

20) Larsell Arch. Neurol. Psprchia1, (1)iengo. 38 ; $580-607,1937$.

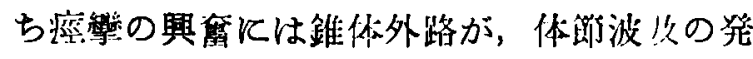
動には錐体路が主導性を有するものと思われ る。

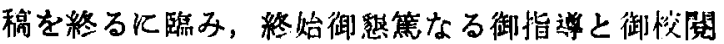
を賜りたる恩们陠内敉授に賁心より深鼠なる感謝の 心を表す。

献

21) Dow Biol. Rew., $17,179-220,1942$.

22）快－1）脳と神経，I；359-369、1949. 口) 脳砄究, 3，86-101，1949.

23) Sachs. Fincher : Brain, 50; 350--356, 1927.

24) Magoun : Amer. J. Physiul., 112; 329-339, 1935.

25) Hare, Ranson J. comp. Neurol., 67 ; 145 $-182,1937$

26) van Rijnberk Das Kleinhirn. Ergeb. d. Physiol. $31 ; 1910$.

27) Rothmann Neurol. zentralbl., 29 ; 1910.

28) André-Thomas, Durupt . 1) Localisations cérébelleuses. 1914.

ㅁ) La fonction cérébelleuse. Paris, Doin et fils, 326, 1911.

29) Ingvar . Brain, $46 ; 1923$.

30) ten ('ate Arch. néerland. Physiol., 10 ; 1925.

31) Adrian . Brain, 66, 289-315, 1943.

32) Nulsen Fed. Proc., 7 ; 86-87, 1948.

33) Snider, Stowell Fed. Proc., 1 ; $82-83$. 1942.

34) Hampson J. Neurophysiol.. $12 ; 37-50$. 1949.

35) Holmes Brain, 40, 461-535, 1917.

36) Rossi Arch. Fisiol., 23 ; 1-19. 1925.

37) Walker Brain, 60 ; 329-353, 1937.

38）增田 . Arb. Hirnanat. Inst. Zürich. 9， 1249, 1914

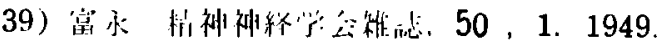

40) Futton Physiolngy of the Norvous Sistem 1949. 


\author{
Department of Surgery, Okayama University Medical School \\ (Director : Prof. Dr. D. Jinnai)
}

\title{
On the march of the cerebellar epileptic convulsion in dogs.
}

By

\section{Futami KOSAKA}

The cpilepte cmavulsion wins caused by local injection of $10 \%$ metrazol in the cerebellar cortex and its march was researched. The results were as follows.

1) The convulsion was identical with the cerebral cortical epileptic convulsion and the number of cases in which the march of spasm was observed was quite the same as that of calses in which the convulsion occurred simultaneously in all parts of body.

2) No convulsion wits ocurred by the stimulation upon the vermis cerebellaris and also

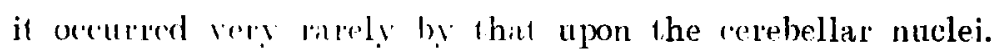

3) In calses having the mareh of spasm calused by stimulation upon Lobus lunatus anterior (L. 1. int.) br.gan in the fore limb, while hy stimuliation upon L. L. inf. and L. semil. mainly in the hind limb on the same side of stimulation.

4) In aises of errebellat slinulation. The pathwas of the impulse was to be between the both wribell.t. hemisphere and both thaliami and thas the march of spasm spread frone cale sicle of the bods 10 the ol her side.

5) No march of the cerebellar epiteptir convulsion orctared without the cerebral motor cortex.

6) Alin the removal of both side of the cerebral motor cortex no march occurred but the general conrulsion occurred simultaneously.

7) No convulsion occurred by stimulation upon the cerebellar hemisphere after the removal of both thalimi or both nuclei lenticulares.

8) The march of convulsion was occurred by it rluse assimilation of pyramidal and extraWrimidal tracts. It seems that for impulse of convulsion the extrapyramidal trate plays important rolr. while for start of march the pyramidal tratel plays mainly. 